\title{
영화교육기관으로서의 한국영화아카데미
}

Korean Academy of Film Arts(KAFA) as A Film Educational Institute

\author{
김정호, 김학민
}

경희대학교 연극영화학과

Jung-Ho Kim(kafa1006@khu.ac.kr), Hak-Min Kim(hakminkk@khu.ac.kr)

\section{요약}

한국영화아카데미는 영화진흥위원회의 전신인 한국영화진흥공사가 미국의 영화시장 개방 압력을 수용 하여 1987년 영화시장 개방을 대비하고 한국영화를 육성하기 위해서 1984년에 설립한 한국영화인력 양성 을 위한 영화학교이다. 2011년까지 배출한 520 명의 졸업생 중에 173 명이 한국영화계의 주요 위치에서 활 동 중이며, 감독은 101 명, 촬영감독은 33 명, 프로듀서 18 명, 영화학과 대학교수 21 명을 배출하였다. 올해로 설립 30주년을 맞이한 한국 영화아카데미는 한국영화시장 개방, 미국영화 직배, 대학에서의 영화교육의 확 산, 대기업의 영화산업 참여, 세대교체, 스크린 쿼터 축소, 디지털 시네마로의 이행 등 한국영화산업의 지형 의 변화에 따라 변화를 거듭하며 현재에 이르렀으며, 앞으로 영진위와 함께 부산이전을 통해서 부산지역 영화산업의 진홍이라는 새로운 과제와 함께 지역 이전에 따른 핸디캡을 어떻게 슬기롭게 극복하는가 하는 과제에 직면해 있다.

| 중심어 : | 영진위 | 영화진흥위원회 | 한국영화아카데미 | KAFA | 한국영화산업 | 한국영화역사 |

\section{Abstract}

Korean Academy of Film Arts (KAFA) is the film school run by Korean Film Council (KOFIC). KAFA was established in 1984, benchmarking American Film Institute (AFA) and in order to foster manpower for Korean Movie under the US's pressure of domestic movie market opening in Korea. The Korean Movie market was open to the world by 1987 and suffered from the low Korean-produced movie market share of around 20\% in the domestic market from 1987 to 1998. During the last 30 years, KAFA plays the key role in the Korean movie making industry. Of 520 of number of their alumni, the number of directors is 101, 33 of cinematographers, 18 of producers and 21 of professors in universities' film departments. Korean Directors, Bong Joon-ho of <Snowpiercer> (2013) and topped over 10 million domestic admissions to become the most-watched Korean films of all time.

Now, with KAFA's relocation to Busan following with KOFIC, their new roles are promotion of the film industry in Busan, recruiting and educating new talented Korean and foreign student filmmakers, becoming an international film school.

keyword : | KOFIC | Korean Film Council | Korean Academy of Film Arts I KAFA | Korean Film Industry |

접수일자 : 2013년 08월 09일 수정일자 : 2013년 10월 10일
심사완료일 : 2013년 10월 10일

교신저자 : 김정호, e-mail : kafa1006@khu.ac.kr 


\section{I. 들어가는 말}

한국영화아카데미(이하 영화아카데미)는 영화진흥위 원회(이하 영진위)의 직제상 기반조성본부에 속한 부서 이다. 기반조성본부장은 한국영화아카데미, 정책연구 부, 기술지원부, 종합촬영소를 관장하며 한국영화아카 데미에는 원장을 두고 있다. 1973년에 설립된 영화진흥 공사(영진위의 전신)는 한국영화시장개방을 대비하며 한국영화 발전을 목표로 1984년, 한국영화아카데미를 설립하여 2013년 현재 30주년을 맞이하고 있다. 영진위 의 역할은 한국영화의 질적 향상과 영화산업의 진흥에 있으며 영화에 관하여 문화체육관광부의 역할을 위임 받아 수행하는 준 정부조직이다. 영진위의 한국영화아 카데미의 운영은 한국영화 진흥을 위해 영진위가 펼치 는 여러 사업들 중의 일환이며, 영화인 재교육을 담당 하는 KAFA PLUS를 포함하여, 영진위의 영화인력 교 육프로그램의 핵심이다. 2013년 기준 한국영화아카데 미의 예산은 18 억5천 7 백만 원으로 이중, 교수 및 조교 인건비로는 4억8천6백만 원, 운영비 4억1천4백만 원, 정 규과정 교육비 9억5천7백만 원을 집행할 예정이다[1]. 정원은 정규교육과정에 영화연출 12 명, 애니메이션 연 출 8 명, 촬영 8 명 등 총 28 명이며, 장편제작을 하는 제작 연구과정에서는 연간 3 편의 장편 극영화와 1 편의 극장 용 장편 애니메이션이 제작된다.

한국 영화아카데미는 27기 2011년 졸업생까지 총 520 명의 졸업생을 배출하였고 이들 중에 173 명이 감독 등 영화관련 주요 위치에서 활동하고 있다[2]. 감독으로는 <설국열차>의 봉준호, <도둑들>의 최동훈, <집으로> 의 이정향, <스캔들 조선남녀상열지사>의 이재용, <8 월의 크리스마스>의 허진호, <결혼 이야기>의 김의석, <영원한 제국>의 박종원, <하녀>의 임상수 등 총 101 명을 배출하였다. 촬영감독은 <국가대표>의 박현철, <살인의 추억>의 김형구 감독 등 33 명, 프로듀서는 노 종윤 등 18 명을 배출하였다. 영화학과 교수진으로는 김 소영, 박종원, 유지나, 이용배 등 총 21 명을 배출하였다.

<실미도>를 포함하여 2003년부터 2013년 상반기까 지 한국영화중에서 1 천만 관객을 동원한 영화 8 편중에 서 봉준호 감독의 <괴물>, 최동훈 감독의 <도둑들> 등
2편이 한국영화아카데미 출신의 작품이며, 2010년 12월 20 일까지의 한국영화 흥행작품 100 위 리스트에서 100 편의 흥행영화를 만든 감독은 총 64 명이며 이들 중 영 화학과 출신자는 총 34 명으로 $53 \%$ 를 차지하며, 100 편의 영화중 47 편을 만들었다. 이들 중 9 명이 한국영화아카 데미 출신자들이다. 봉준호, 최동훈, 이정향, 이재용, 임 상수, 신태라(7급 공무원), 민규동(내 생애 가장 아름다 운 일주일), 오기환(작업의 정석), 귄칠인(싱글즈) 등이 그들이다. 오기환과 신태라는 영화학과를 나오기도 하 였다. 한양대 출신 감독은 총 9 명이고, 중앙대 출신은 7 명, 서울 예대 5 명, 동국대 3 명, 용인대 1 명이 이들 흥행 감독들을 배출하였다[3]. 한국영화아카데미 졸업 작품 의 예술적 성취를 최근의 영화제 초청 혹은 수상실적으 로 살펴보면, 2006년부터 2012년 1월까지를 놓고 보았 을 때, 윤성현의 <파수꾼>을 포함하여 총36편이 48개 의 국내외영화제에 출품되어 38 회의 수상기록을 보여 주고 있다.

올해로 설립 30주년을 맞이한 한국 영화아카데미는 한국영화시장 개방, 미국영화 직배, 대학에서의 영화교 육의 확산, 대기업의 영화산업 참여, 세대교체, 스크린 쿼터 축소, 디지털 시네마로의 이행 등 한국영화산업의 지형의 변화에 따라 변화를 거듭하며 현재에 이르렀으 며, 앞으로 영진위와 함께 부산이전을 통해서 부산지역 영화산업의 진흥이라는 새로운 과제와 함께 지역 이전 에 따른 핸디캡을 어떻게 슬기롭게 극복하는가 하는 과 제에 직면해 있다. 본 글에서는 한국영화아카데미의 그 동안의 과정과 성과를 살펴보고, 부산이전이라는 새로 운 도전에 직면한 한국영화아카데미의 새로운 방향성 을 살펴보고자 한다.

연구방법은 신문 등 언론에 보도된 내용과 관련 보고 서를 중심으로 문헌연구를 진행하였다. 기사가 작성될 시점에 기자들이 기사의 가치를 판단하는 과정을 수행 하였기에 객관적이며 뉴스적인 중요성을 지닌 내용을 중심으로 하였다. 현재의 한국영화사 연구 방법은 식민 지 시대의 경우, 당시의 언론보도, 잡지, 문예지 기고문, 일본어 문헌 등에 바탕을 둔 문헌 연구가 주종이며, 60-70년대 한국영화사 연구는 문헌연구와 당시에 활동 하였던 구술연구가 병행되고 있다. 
한국영화사의 일부분이라고 할 수 있는 한국영화아 카데미라는 주제를 가지고 진행된 기존의 연구가 몇몇 보고서에 불과한 현 상황에서 본 연구는 한국영화아카 데미라고 하면 '아 그거' 정도만을 떠올리게 되는 현단 계에서 나아가서 본격적으로 한국영화사 속에서 한국 영화아카데미의 역할을 탐구할 시발점으로 삼고자 한 다. 그렇게 하기 위해서, 우선 이 연구에서 다룬 부분은 30 여년간의 한국영화아카데미의 개괄적 흐름이다. 그 리고 그 흐름에 대한 서술의 객관성을 높이기 위해서 취한 방법은 신문기사를 중심으로 한 문헌연구이다. 한 국영화아카데미 출신의 감독이나 동문들의 개별적 인 터뷰를 통해서 연구를 하는 방법도 있으나, 이 경우 자 칫 가십성으로 흐르기 쉽고, 주관의 개입의 우려가 크 다. 정량적 연구로서, 영화 아카데미에 들어간 예산, 한 국영화의 점유율, 지원율, 감독 데뷔율, 영화계 종사 비 율, 감독 데뷔까지 걸리는 기간, 출신 감독들의 관객 동 원율, 영화제 수상실적, 영상원 및 국내외 대학 영화학 과와의 비교 등을 수행할 수 있을 것이나, 우선은 구체 성을 띈 한국영화아카데미의 모습을 담고자 정성적 연 구를 진행하였다. 영화아카데미 합격생의 출신 대학이 나, 지원율 등을 언급한 것은 그때 당시의 한국영화아 카데미를 영화지망생들이 어떻게 바라보고 있으며, 언 론계를 중심으로 한 시각도 확인하기 위한 방편으로 활 용하였다. 초창기에는 합격생의 이름과 출신대학도 신 문지상에 기사로서 처리되었으나, 점차 영화아카데미 의 독점적 지위가 사라지면서 이러한 신문기사도 사라 짐을 알 수 있다.

\section{1984년 한국영화아카데미 설립}

\section{1. 외국영화시장 개방과 이에 대비하는 한국영화 계의 선택}

1983년 10월 27일, 문화공보부는 미국의 외국영화수 입시장 개방요구에 대응하고, 한국영화의 질적 향상과 국제 진출을 강화하기 위한 영화진흥 5 개년 계획을 발 표한다. 그 계획의 핵심은 영화진흥을 위한 조사, 연구 및 영화인 양성을 위한 교육 훈련을 전담할 전문기관으
로 한국영화아카데미를 두고 1988년까지 50여명을 선 발 양성하는 방안과, 한국영화복지재단을 설립하여 영 화인 대상 연금지급, 장학금 지급, 영화 소재 및 시나리 오 발굴을 위한 시나리오 뱅크의 설치이다[4].

이에 따라서, 영화진흥공사(영진위의 전신)는 1984년 3 월1일 영화아카데미를 설립한다. 영화아카데미의 역 할은 불황에 놓인 한국영화진흥을 위해 창안과 기회 조 사연구와 영화인 양성을 위한 교육훈련전문기관이다. 전문대 이상 학력자를 대상으로 연출, 촬영을 지망하는 인력 10 명을 선발하고, 미국과 일본에 연수 및 시찰의 기회도 부여하고[5], 1 년 과정으로 연간 48주의 실습교 육을 실시하며 85년부터는 2년제로 확대할 예정이었다 [6].

1984년 1월27일에 각 신문지상에 광고된 제 1기 영화 아카데미 신입생 모집요강을 보면, 총 12 명의 인원을 선발하며, 전문대 졸 이상의 학력자로 만 30세 미만의 자이며, 남자는 병역필이나 면제자여야 지원 자격이 있 으며, 전형방법은 3 차에 걸쳐 이뤄졌다. 1 차 기초소양으 로 영화 일반 및 영어 필기시험을 실시하고, 2 차는 자질 및 실기 평가로서 작품평가 및 구성 능력을 본다. 3 차에 서는 면접으로 이뤄졌다. 교육기간은 1년 48주 1,800 시 간으로 수업료는 무료였다[7]. 1기 모집에는 81명이 응 모하여 12 명이 최종 선발됨으로써 6.75 대 1 의 경쟁률을 보였다 합격자의 이름과 출신학교가 신문에 실리기도 하였으며[8], 합격자는 오병철, 장현수, 김의석 감독 등 중앙대 연극영화학과 출신 3 명과 한양대 연극영화학과 출신 박종원 감독 1 명과 비영화학과 출신 8 명으로 서울 대 2 명, 연세대 2 명, 서강대 영문과 출신 1 명(현 영상원 교수 김소영), 이대 불문과 출신 1 명(현 동국대 교수 유 지나), 서울시립 산업대 1 명이다. 서울대 출신은 조경학 과의 이용배(현 계원예대 교수)와 독문과의 황규덕(감 독, 현 명지대 교수)이다.

1985 학년도에는 촬영분야 6 명, 감독 분야 6 명을 선발 한다고 하며 나이제한을 27 세 이하로 한정하고 2 차 전 형에서 작품구성능력과 공간구성능력을 평가한다고 광 고하였다[9]. 1985년의 한국영화계의 상황을 보면, 50여 편의 영화중 2 편정도의 비율로 흥행에 성공하였으며, 배창호 감독의 <깊고 푸른밤>이 명보극장에서 495,673 
명, 이장호 감독의 <어우동>이 단성사에서 479,225 명 의 관객을 동원하여, 각각 80 년대 국내 영화흥행순위 9 위와 11 위를 기록하였다. 이 당시에는 현재의 멀티플렉 스 극장에서 수백 개의 스크린에 동시 개봉하는 형태가 아니라, 각 지역별로 극장 1 개소에서 장기간에 걸쳐서 상영하는 상영방식으로 이 시기의 관객집계는 서울지 역 개봉관에서의 흥행실적이며 보통 서울의 개봉관에 서 10 만 명을 넘으면 성공하였다고 본다. 이 두 편의 영 화의 경우, 그 당시 한국영화 통상 제작비 규모의 2-3배 인 2 억5천만 원에서 2 억6천만 원의 제작비가 들어갔다 [10]. 1985년에는 영화제작업과 수입업의 분리가 7월 3 일자로 시행되었으며, 영화사의 경우 허가제에서 등록 제로 바뀌어 종전에 정부의 허가를 받은 20 개의 영화사 가 영화업을 독점하던 체제가 해체되었다. 한국영화점 유율은 94년 38.5\%, 85년 34.2\% 이었다.

1986학년도에는 감독 및 촬영분야로 모집은 하였으 나, 분야별 인원을 한정하지 않았으며, 나이제한은 다시 만 30세 미만으로 환원되었다[11]. 1986년에는 외화수 입업이 자유화되어서 외국영화수입사가 54 개사로 늘어 났으며, 문공부는 1986년 4월2일에 한국영화발전시책 을 발표하는데 그 중요 내용은 외화수입업자와 한국영 화 제작자에 대한 등록 예탁금을 종전의 외화 7 억 원, 방화 1 억 5 천만 원에서 각각 5 천만 원으로 대폭 인하, 프 로덕션 제작에 대한 제작비의 사전 예치하던 예치금의 규모를 종전의 $90 \%$ 에서 $10 \%$ 로 사전예치금 대폭 삭감, 문예 진흥 기금에서 $20 \%$ 를 국산영화진흥기금으로 전 용 등을 골자로 하고 있다[12]. 참고로 1987년 은마 아 파트 32평의 가격은 3000만 원대였고, 1987 년 성인 관 객 서울 개봉관 외국영화 입장료 평균 3 천 -3 천 5 백 원, 한국영화 2 천 5 백 원, 서울 시내 변두리 소극장 재개봉 관 입장료 1천원[13], 1987 년 짜장면 가격 500원-1500 원, 1990년의 서울 극장입장료가 4천원임을 고려하면, 여전히 영화업에 진입하기에는 상당한 자본이 필요하 였음을 알 수 있다. 1986년에는 故 곽지균 감독의 <겨 울 나그네 $>$ 가 서울에서 22 여만 명의 관객을 동원하였 으며, 1986년 상반기 동안 제작된 32편의 영화중에서 성인물영화는 27 편이나 차지하여 전반적인 한국영화의 질이 뛰어난 상황은 아니었다.
1987학년도에는 교육비 중 실습용 네가 필름대 40만 원을 교육생에게 부과한다고 공지하였다[14]. 아카데미 4 기생이 되는 87 년도 입학생은 지원자 43 명중에서 여 자 2 명을 포함한 16 명을 선발하여, 경쟁률은 2.7 대 1 이 었으며, 서울예술대학출신자가 5 명, 한양대 3 명, 연세대 2 명, 동아대, 동양공전, 서강대, 외대, 홍익대, 중앙대 각 각 1 명씩이며 영화전공자는 4명이다[15]. 1987년에는 시나리오 사전 심의 폐지 및 심의 완화가 이루어졌으며 7월1일자로 수입 자유화와 영화시장이 개방되었다. 그 래서 1988년에는 미국의 UIP가 <위험한 정사>를 직접 배급하여, 서울의 개봉관 2 개소에서 65,099 명의 관객을 동원한다. 1987년 한 해 동안 수입된 외화는 1 백 75 편이 다. 한국영화점유율은 86년 33\%, 87년 27\%, 88년 $23.3 \%$ 이었다.

\section{1 기 졸업생의 첫 감독 데뷔와 기술(녹음)요원 선발}

1988 년에는 한국영화아카데미 5주년을 기념한 영화 제가 영화진흥공사에서 11 월14일부터 개최되어 김의석 감독의 <창수의 취업시대> 단편영화가 상영되었다 [16]. 5년간 배출된 53 명의 영화인력 중, 1 기인 박종원 감독이 화천공사에서 이문열의 소설 <구로 아리랑>을 연출하여 1989년 감독 데뷔한다. 장선우 감독의 <붉은 방> 연출부로는 1 기의 임종재, 4 기의 정병각 감독이 시 나리오 작업에도 참여한다[17].

1989학년도에는 연출 및 촬영 10명, 기술 분야 (녹음) 6 명을 모집하고자 하였으며, 실습용 필름대 40만원을 받는다고 광고하였다[18]. 기술 분야 지원자는 향후 해 외연수 등을 통해서 영화진흥공사 기술요원으로 채용 할 예정이었다. 1990학년도 영화아카데미 신입생 모집 에서는 연출 및 촬영부문 8 명과 기술 분야(녹음, 현상 등) 4 명을 선발한다. 기술 분야 모집은 91 학년도에도 4 명을, 전자, 전기, 기계, 화학 등 유관학과 전공자를 대 상으로 선발하여 해외기술연수 등을 통해 영화진흥공 사의 기술요원으로 채용한다.

\section{1987년 민주화와 졸업 작품 시나리오 검열문제}

87년 민주화 이후, 영화계에서도 독립영화제작 분위 
기가 조성된다. 1988 년에는 영화제작소 장산곶매가 광 주항쟁을 다룬 $16 \mathrm{~mm}$ 장편 <오! 꿈의 나라>와 <파업 전야>가 상영되었고, 당시 장산곶매의 대표를 맡고 있 던 1 기 이용배는 제작신고와 심의과정을 거치지 않았 다는 이유로 기소되었다. 영화아카데미 4기 출신으로 이뤄진 “영화공장 서울" 은 <네 멋대로 해라>의 촬영을 시작한다. "영화공장 서울”의 대표 김태균, 감독 오석 근, 촬영 김형구는 모두 영화아카데미 4기출신이다. 1 기 황규덕 감독(30세 감독 데뷔)도 독립프로덕션 “물결”을 설립하고 <꼴찌에서 일등까지 우리 반을 찾습니 다>(1990)를 연출한다[19]. 이 영화는 1990년에 완성되 어 개봉된다. 3 기 출신 안재석 감독은 영화아카데미 졸 업 작품을 확대하여 28세에 <회색도시 2>(1989)를 젊 은 영화집단 '시네피아'를 결성하여 촬영한다. 독립프로 덕션 영화제작소 '청기사 그룹'에서 곽재용 감독이 <비 오는 날의 수채화>를 만들었다[20].

89 년 한 해 동안 한국영화는 1 백10편이 제작되었으며 독립프로덕션에서는 19편을 제작하였고 수입된 외국영 화는 2 백 64 편이다. 89 년의 한국영화 점유율은 $20.2 \%$ 이 었다. 한편 영화진흥공사에서 영화진흥책 수립을 위해 서 영화인 1 천여 명을 대상으로 실시한 설문조사에서 시급한 과제로 사전 사후 시나리오 지원 등 제작비 지 원, 종합촬영소 건립, 시설 장비의 현대화, 한국영화아 카데미의 학제를 1 년에서 2 년으로 확장 등이 필요하다 고 조사되었다[21]. 영화인들이 영화아카데미 2년제화 를 제시하였다는 것은 어느 정도 한국영화아카데미의 효용성이 기존 영화인들에게 인식되고 있으며 충무로 에 새로운 고급 인력이 유입되고 있다는 긍정적 영향을 보여주고 있다고 본다.

중앙대 영화학과 민족영화연구회 '광야'와 '해방영화 집단'이 만든 전교조 관련 $16 \mathrm{~mm}$ 60분 영화 <선생님 사 랑합니다>와 경희대 영화동아리 그림자놀이가 제작한 13 분짜리 $16 \mathrm{~mm}$ 영화 <선생님 그리기> 등 사회 민주 화를 반영하는 독립영화들이 제작되고 상영되는 분위 기가 확산되는 가운데[22], 한국영화아카데미에서는 졸 업 작품에 대한 사전 시나리오 검열문제가 발생한다. 13 명의 연출 전공자와 1 명의 촬영전공자로 구성된 영 화아카데미 6기 재학생들이 졸업 작품 제작을 위해 제
출한 시나리오 중 3 편의 시나리오의 반려가 작품성이 나 미학적인 기준이 아닌 소재 제한의 일환으로 이뤄졌 다는 문제 제기이다. 영화아카데미는 졸업 작품 편수를 7편으로 제한하고 있는데, 학생들이 제출한 시나리오를 지도강사가 평가하여, 졸업 작품 제작에 착수할 수 있 을지를 결정한다. 탈락된 세편의 시나리오는 실종된 청 년 노동자를 다룬 홍준석의 <별이 되어 만나리>, 전대 협 대표로 북한을 방문한 임수경씨의 언니 윤경씨를 주 인공으로 하여 가족의 고통과 분단 극복을 다룬 금보상 의 <아리랑 고개를 넘어>, 학원 프락치를 다룬 김은주 의 <슬픈 시>이다[23]. 영화아카데미 나한태 원장과 지도강사 최하원 감독은 아카데미 졸업생들의 졸업 작 품이 공연윤리 위원회의 심의를 받아서 외부에 상영되 어 왔다는 점을 들어 일반 공연물처럼 소재제한이 필요 하다는 입장이며, 이에 대해 한국영화아카데미 6기생들 은 졸업 작품 제작을 거부하고, 창작의 자유와 소재 선 택의 자유 보장, 예술적 기준으로 탈락 작품을 재평가 할 것 등을 요구하는 '89한국영화아카데미 졸업 작품 소재 제한에 대한 우리의 입장'이라는 성명서를 89 년 11 월21일 발표한다[24]. 민족예술인 총연합, 한국영화조 감독협의회, 한국영화역사연구위원회, 대학연극영화과 협의회, 독립영화인대책위원회 등 5 개 단체는 12 월 2 일 공동성명을 통해서 영화아카데미원생의 소재제한과 사 전검열 중단을 요구하고 유신정권이래 영화를 독재정 권에 종속시키는 역할을 하여왔던 영화진흥공사의 해 체와 영화인의 요구와 지향을 담은 영화진흥기구의 발 족을 주장하였다[25]. 소재제한에 반대하던 재학생 9명 은 임수경 가족의 이야기를 다룬 시나리오 <아리랑 고 개를 넘어>를 바탕으로 $16 \mathrm{~mm}$ 20분 영화 <슬픔을 자 르고>를 만들어서 1990년 3월23일 한국독립영화협의 회가 주최하는 제 1 회 독립영화제에서 대학의 프락치 사건을 다룬 한양대 연극영화학과 학생들이 주축으로 제작한 <친구여 이제는 내가 말할 때>와 중앙대 영화 패가 만든 <선생님! 사랑합니다>와 함께 상영된다[26].

1982 년부터 등장한 소극장이 늘어나 5 백여 개가 되고 통금해제로 밤 11시 이후 영화를 상영하는 심야극장이 등장하기 시작한 1980 년대에는 87 년, 강수연이 임권택 감독의 영화 <씨받이>로 제 44 회 베니스 영화제 최우수 
여우상을, 88년 몬트리올 영화제에서 신혜수의 최우수 여우상 수상(임권택 감독의 <아다다>), 89년 모스크바 영화제에서는 강수연이 <아제 아제 바라아제>(임권택 감독)로 최우수여우상을 수상하고, 배용균 감독이 <달 마가 동쪽으로 간 까닭은>으로 로카르노 영화제 그랑 프리를 수상하는 등 국제영화계 진출이 확대되었다.

\section{III. 한국영화 점유율 $20 \%$ 대의 1990 년대}

90년대 들어서 한국영화점유율은 $20 \%$ 대에서 머문다. 1990 년의 $20.2 \%$ 의 점유율에서 1999 년의 $39.7 \%$ 의 점유 율 사이에서, 최고 $25.5 \%$ 의 1997년, 최저 $15.9 \%$ 의 1993 년 점유율은 기록한다. 90년대 초반부터는 한국영화아 카데미 졸업생을 비롯하여, 대학에서 영화를 전공한 인 력들의 감독 데뷔가 두드러지게 되었다. 특히 해외 유 학파의 감독 데뷔가 많아지던 시기였다. 영화아카데미 1 기 김의석 감독(35세 감독 데뷔)은 <결혼 이야 기>(1992)로, 4기 이현승 감독(32세 감독 데뷔)은 <그 대안의 블루>(1992)로 데뷔한다. <결혼 이야기>는 92 년 서울 피카디리 극장에서 개봉되어 서울 개봉관 기준 50 만여 명의 관객을 동원하여 한국영화 흥행 1 위를 기 록한다. 20여명의 30대 감독들의 데뷔러시를 1985-6년 의 장길수, 신승수, 곽지균, 김유진, 유영진 등의 감독 데뷔 러시에 이은 7년만의 현상으로 직배외화에 대한 한국영화계의 자구책이라는 분석이 나오기도 하였다 [27]. 92년 한국영화는 96 편이 제작되었으나 이중 $81 \%$ 인 62편이 멜로, 에로물이었다. 흥행 면에서는 서울 개 봉관 기준으로 10 만 명 이상 동원한 한국영화는 <결혼 이야기>, <미스터 맘마>, <경마장 가는 길>, <하얀 전 쟁>, <장군의 아들 3 편> 등 6 편에 불과하였다. 반면에 외화는 미국 직배영화 61 편을 포함하여 420 편이 수입 되었고 관객동원에 있어서도 1 백 13 만 명을 동원한 <원 초적 본능>을 비롯하여, 30만 명 이상을 동원한 영화가 10 여 편이 되었다[28]. 92년에 수입된 420편의 대다수는 미국과 홍콩영화였고, 420 편수는 그해 전 세계에서 제 작된 영화의 약 10 분의 1 에 해당된다.

\section{1. 〈호모 비디오쿠스〉의 국제영화제 진출}

한편, 한국영화아카데미 7기인 이재용과 변혁이 공동 연출한 졸업 작품인 <호모 비디오쿠스>가 제35회 샌프 란시스코 국제영화제 단편부분 최우수 작품상, 제 38 회 오버하우젠 국제단편영화제 국제경쟁 부분 진출[29], 93년 클레르몽페랑 단편영화제 심사위원 특별상, 예술 공로상 수상[30], 등으로 한국영화아카데미 졸업 작품 의 예술적 성과를 증명하였다. <호모 비디오쿠스> 이 후, 한국영화아카데미, 영상원, 대학 영화과 단편작품들 의 해외영화제 진출이 활성화되었다. 한편 한국영화아 카데미는 92 학년도에는 연출과 촬영 분야에서 10 명을 모집한다. 한국영화아카데미가 여타 대학교의 연극영 화학과보다 장비와 시설에서 월등하였던 관계로 동일 한 경쟁조건이 아니라는 점을 감안하여, 한동안 한국영 화아카데미의 작품들을 국내 단편영화제에 출품하는 것을 자제하는 분위기가 있었다.

\section{2. 단발로 끝난 연기자 선발과 케이블 TV의 등장}

1993년에는 영화아카데미에서 처음이자 마지막으로 연기자를 모집하였다. 93 학년도에는 모집 인원 12 명으 로 연출과 연기 분야를 모집하여 남자배우 1 명, 여자 배 우 1명을 선발하고, 촬영분야는 모집하지 않았다[31]. 93년 11월12일에는 남양주 종합촬영소가 완공되었고, 12 월14일에는 서울 홍릉의 세종대왕기념관 근처에 영 화아카데미 건물 신축 기공식이 열렸다. 연면적 2천1백 58 평, 지상 3 층, 지하 2 층으로 68 억의 예산으로 95 년 3월 에 완공할 예정의 이 건물의 원래 용도는 영화 아카데 미 강의, 연구실, 녹음실, 시사실의 용도[32]이었으나, 1995년 10월 남산에 있던 영화진흥공사와 영화아카데 미가 이주하여 사용하게 된다. 이렇듯, 표면적으로 영화 아카데미의 교육용 시설 및 장비 구축용 예산으로 형성 된 $35 \mathrm{~mm}$ 영화촬영용 카메라와 영화진흥공사의 시설은 영화아카데미 학생들보다는 한국영화산업현장에 장비 와 시설 대여용으로 많이 활용되었다.

한편, 1994년은 우리나라에서 케이블 TV가 본격적으 로 활성화되는 시기로, 영화 아카데미 10기생 절반이 케이블 TV에 종사하기도 하였다. 또한 10 기생중의 5 명 은 미국 유학을 마치고 1999년 이후, 우리나라 대학교 
에 영화관련 학과가 많이 설치되던 시기에 각 대학의 영화학과 교수로 진출하여 1 기생 이후 최다 교수진을 배출한다. 1994년에 영상산업발전 민간협의회는 영화 와 컴퓨터 게임 등 영상산업발전을 위한 종합보고서를 발간하는데, 영상산업 전반을 제조업 범주로 분류하여 세제와 금융혜택을 주는 것과 현행 한국영화아카데미 를 국립영화학교 혹은 특수대학원으로 개편하여 전문 인력을 양성하는 방안 등 2천 년대를 대비한 산업육성 방안이 제시되었다[33]. 93년의 한국영화 점유율은 $15.9 \%$ 로 90년대 최저를 기록하였으며 94년은 $20.5 \%$ 였다.

\section{3. 한국예술종합학교 영상원의 개교}

그러나 국립영화학교의 지위는 1995년 3월8일 개원 한 한국예술종합학교 영상원의 몫이었다[34]. 이때 입 학한 46명의 학생들은 대부분 대학 재학생이거나 대학 졸업생이었으며, 고등학교에서 바로 영상원으로 들어 온 학생은 소수에 불과하였다. 영상원의 등장을 계기로 한국의 영화교육현장은 중앙대, 동국대, 한양대 등 사립 대학의 연극영화학과와 한국영화아카데미, 영상원으로 확장되게 된다. 영상원은 대학과정으로서 같은 대학과 정인 사립대학의 연극영화학과에게도 위협적인 요인이 되었다. 이러한 경쟁관계는 대학입시의 수시에서 우수 학생을 확보하고자 하는 영상원과 중대, 동국대의 대응 에서도 찾아볼 수 있다. 한국영화아카데미는 지원 자격 으로 전문대졸이상으로 설정하여, 학부보다는 사립대 학의 대학원 과정과의 경쟁관계이었으며, 영화아카데 미의 제작중심과 대학원 이론중심으로 어느 정도 분업 화가 되었으며, 학부와는 영화전공 학생들이 졸업 후 진학할 수 있는 미래의 목표 설정으로도 역할을 하여, 학부에서 열심히 해야 한다는 동기부여도 되는 측면이 있었다. 한국영화아카데미에는, 영화 비전공자이면서 대학 재학생이나 졸업생이 영화를 만들고자 할 때, 선 택하여 지원할 수 있는 경우의 수가 영상원과 영화 아 카데미로 2원화 되어서 현재까지 우수인재를 독점적으 로 확보하던 시기가 끝났음을 의미한다. 물론, 영상원은 4 년제이고, 영화아카데미는 1 년제라서 들어가는 비용 측면에서는 영화아카데미가 유리하나, 세계최고 수준 의 시설과 장비를 갖춘 영상원에서 얻을 수 있는 것은
상당하다. 영상원 1 기가 졸업하는 1999 년에, 영상원 1 기 졸업생들은 마치 영화 아카데미 1 기가 경험했던 것과 같은, 1 기라는 프리미엄과 영화계의 관심 속에서 깐느 영화제 단편영화부분 진출 등으로 주목을 받게 되고, 촬영과 연출 분야에서, 기존의 경력과 나이 중심의 관 행을 깨뜨리면서 충무로에 성공적으로 안착하게 된다. 하지만 점차, 고등학교에서 바로 영상원으로 진학하는 경우가 많아지면서 초기 영상원의 약진은 약해지고, 영 상원은 학부의 인문교육을 강화하고, 학부에서 영화전 공자와 비전공을 대상으로 하는 전문사 즉 대학원 과정 을 강화하는 전략을 취하면서, 다시 영화 아카데미, 사 립대학 대학원과의 직접적인 경쟁관계가 된다. 세 기관 중에, 영화아카데미는 제작실기 석사 즉 $\mathrm{MFA}$ 학위를 줄 수 없다. 이점이 약점이면서도, 사립대학의 대학원과 공존할 수 있는 방편이기도 하다. 즉 대학교 등지에서 영화를 가르치는 교육 쪽의 일자리를 생각한다면, 다시 사립대학에서 학위를 받아야 하는 것이다. 2013년 현재 영상원 영화과 교수 12 명중에 4 명이 한국영화아카데미 출신이고, 영상이론과의 김소영을 포함하면 총 5 명이다.

\section{4. 단편영화에 대한 위상 변화와 사설영화학교 설립 붐}

이제까지는 학생들의 실습작품으로만 치부되어 왔던 단편영화들이 일반 대여시장을 통해서 더 많은 관객을 만나게 되기 시작한 것은 인디라인이 국내 단편영화를 묶은 비디오를 제작하였고, <창수의 취업 시대>, <호 모 비디오쿠스>, 등 영화 아카데미의 졸업 작품들이 비 디오로 출시하였고, 단명하였지만 삼성이 개최하였던 서울 단편영화제와 그 작품집이 나오던 1995년부터이 다[35]. 동숭 씨네마텍과 코아 아트홀은 1996년부터는 극장에서 본 영화 상영 전에 단편 영화를 상영하여, 단 편영화에 대한 일반의 인식에 변화를 가져왔다[36]. $\mathrm{VHS}$ 를 대체하는 $\mathrm{DVD}$ 의 등장과 단편영화에 대한 인식 의 전환에 따라서, 영화제에서 상영되거나, 혹은 학교에 서 과제로 만들어진 뒤 사장되어 버리던 단편영화를 비 롯한 독립영화와 예술영화를 $\mathrm{DVD}$ 로 출시하는 경향이 늘어나게 되었으며 영화아카데미도 '카파(KAFA) 2002 컬렉션' 이라는 졸업 작품 $\mathrm{DVD}$ 를 제작하기 시작하였 
다[37].

1996년도에 들어서면서, 영화아카데미는 기존의 1 년 과정에서 6 개월을 연장하여 3 학기 체제로 18 명의 신입 생을 모집한다. 입시전형에서도 변화를 가져와서, 1 차 에서 영어, 작품구성, 공간구성, 2 차에서 포트폴리오(참 여, 제작한 작품) 평가, 3 차 면접 및 신체검사로 선발하 게 된다[38]. 1차에 치르던 영화상식에 대한 지필고사가 없어지고, 2 차에서 평가하던 작품구성과 공간구성을 1 차에서 함께 치르며, 2 차에서는 포트폴리오 평가가 신 설되었다. 이는 비디오카메라 보급 확산과 사설 영화교 육기관, 독립영화 단체의 교육과정 등이 많아지면서 가 능하게 되었다. 이 해에는 총 156 명이 응시하여 8.6대1 의 경쟁률을 보였다[39]. 한편, 한국영화조명감독협회 에서는 조명 분야 조수를 원활히 확보하고, 조명분야 전문 인력을 양성하고자 하는 조명아카데미를 3개월 과정으로 개설한다[40]. 이러한 '아카데미'에 대한 선호 는 재즈 아카데미, 케이블 TV 등장으로 인력 수요가 많 은 방송 아카데미, 등에 대학의 전공과는 무관하게 전 문분야로 진출하고자 하는 젊은이들이 많아지면서 언 론의 주목을 받기도 한다. 1996년의 영화아카데미 신입 생 18 명 중 절반가량이 서울대, 연세대, 이화여대 등 명 문대 출신이라는 점이 신문에 다뤄지기도 한다[41]. 'NeO 영화학교' 등 국내 사설 영화학교가 늘어나는 시 기도 이 시기이다[42]. 1998년에는 결과적으로는 불발 로 끝났지만, 예일 디자인 아카데미가 미국의 $\mathrm{AFI}$ 와 함께 KFI(한국영화원)을, 네오영화학교가 프랑스 ISCEC 분교를 설립하고자 시도할 정도로 영화교육과 외국 영화유학에 대한 수요가 늘어나고 있었다[43].

\section{5. 졸업생의 첫 촬영감독 데뷔}

한편 영화아카데미 촬영 졸업생의 첫 촬영감독 데뷔 도 1996년 전후로 이뤄졌다. 1995년에 <닥터 봉>의 김 형구(36세 촬영감독 데뷔), 96년의 <채널69>의 박현철 은 중앙대 사진학과, 한국영화아카데미, 미국의 영화학 교 $\mathrm{AFI}$ 를 거쳤고, <미지왕>의 진영환(38세 촬영감독 데뷔) 등 아카데미 4기 출신 3 명이 데뷔하게 된다. 이 시기에 충무로 도제시스템에서 성장한 촬영감독으로 는, 1977년 고등학교를 졸업하고 충무로에 들어온, <은
행나무 침대>의 박희주 촬영감독(34세 촬영감독 데뷔), <정글 스토리>의 변희성(33세 촬영감독 데뷔), <학생 부군 신위>의 최정우(37세 촬영감독 데뷔)가 있다.

신인촬영감독의 데뷔가 가능해진 것은 이전까지 한 국영화촬영감독협회의 인준을 받아야만, 조명감독협회 의 도움을 받고, 극장에 영화를 틀 수 있다는 카르텔이 약화되고 있어서 가능해졌다. 촬영감독의 인준 절차는 만 5년 이상의 촬영조수 경력과 기존 촬영감독 3명 이 상의 추천을 받아서, 촬영감독협회의 심사를 거치고 이 사회에서 과반수의 찬성을 얻어야만 촬영감독이 될 수 있게 만들어 놓은 협회의 장치로[44], 이 인준제도가 새 로운 피의 충무로 진입을 막고, 조수생활 10년을 하여 도 인준을 받지 못하는, 기득권을 보호하는 일종의 노 예제도처럼 작용하여 왔다. 1960년대 한국영화의 호황 기에 20대의 나이로 데뷔하였던 촬영감독과 연출 감독 들은 70-90년대까지 정부의 통제와 당근으로 전성기를 누리고, CJ가 영화제작에 본격적으로 참여하는 1999년 을 기점으로 60-70대라는 연령대와 새로운 디지털 기 술에 도입 등의 원인으로, 점차 세력이 약해지고 한국 영화의 세대교체는 모든 분야에서 급격히 이뤄지게 된 다. 실질적인 충무로 도제시스템이 무너지고, 영화학교 출신 등이 조수 생활 없이 혹은 짧은 조수 생활을 거치 거나 단편영화, 독립 장편영화를 통해서 바로 촬영감독 이나 영화감독으로 데뷔하게 된다.

\section{2000년대: 한국영화의 세대 교체}

한편, 우리나라는 1997년에 IMF 체제를 겪으면서, 이 해 제작된 한국영화는 59 편이고, 기존의 삼성, 대우 등 대기업이 영화 사업에서 철수하게 되는 반면에, CJ는 1998년에 ‘CGV 강변11' 등 멀티플렉스 영화관을 도입 하면서 본격적으로 한국영화계에 진출하게 된다. 1998 년의 한국영화 시장점유율은 $25.1 \%$ 이고, 한 해 제작된 한국영화는 43 편이다. 이 시기 한국영화 제작비는 평균 6억-7억 선이었다. 1999년에 들어서면서, 한국의 대학 들에는 영화 관련학과 건립 붐이 마지막으로 불어 닥친 다. 이 시기에 국민대, 경희대, 동서대 등에 연극영화학 
과들이 설치된다. 그 결과, 2012년 12월 현재 4년제 대 학 74 개소, 2,3 년제 대학 16 개소에 영화, 영상, 연기 관 련 학과가 설치되어 있다[45]. 또한 1999년에는 1기 학 부과정 졸업생이 배출되던 한국예술종합학교 영상원에 대학원과정인 전문사 과정이 설치되었다. 디지털 비디 오의 확산에 따른 영상매체의 민주화와 영상제작의 대 중화, 사설 영화교육기관의 성황, 해외 영화유학 증가, 대학교의 영화관련 학과 설치 붐, 국립영화학교로서 영 상원의 학사과정과 전문사 과정의 설치는 한국영화아 카데미의 위상과 역할에 새로운 변화를 요구하게 된다. 그러한 위기는 1998년 8월부터 2001년 8월까지 한국영 화아카데미 주임교수를 역임한 황규덕 감독의 토로에 서 표출된다. 그는 1984년부터 1998년까지 한국영화아 카데미 주임교수를 맡았으며 영화진흥공사 상무를 역 임한 최하원 감독의 후임이었다. 황규덕은 김영삼 정부 에서의 영상원 설치에 따른 중복투자 논란, 영상원에 대한 투자규모, 기획예산처의 긴축재정방침에 따른 영 화진흥위원회의 홀대, 36 명의 재학생에 행정직원 2 명, 주임교수 1 명, 조교 2 명, 교육기간 2 년에 동결된 예산, 시설과 장비의 노후화 등을 언급하였다[46]. 99년도의 한국영화아카데미의 예산은 2 억1천6백9십7만3천원이 었고, 98 년부터 학생을 뽑은 애니메이션 아카데미의 99 년 예산은 24 명의 학생에 1 억3천6백6십만 원이었다. 1999년 11월 문광부가 발행한 보고서에서는 영화아카 데미가 설치된 시기와는 달라진 영화교육환경과 영화 계를 언급하면서, 연출중심의 교육에서 사운드, 현상 등 기술스태프 위주의 교육을 통한 전문기술 인력 양성, 영화 비전공자보다는 대학에서 영화를 전공한 학생들 을 중심으로 한 교육, 우수 교수와 충분한 작품 제작을 위한 예산 증대, 한국영화아카데미 전용의 장비와 시 설의 확충, 대학교육과의 연계를 위해서 정규 대학원 과정으로의 개편 등을 제안하였다[47]. 하지만 인간간 의 관계와 갈등, 그리고 그 인간들이 살아가는 사회의 제반현상을 반영하는 영화라는 예술의 특성상 인문학 적 토양 등 다양한 전공의 비전공자들이 가진 장점은 결코 무시할 수 없다. 영화는 음악이나 무용처럼 조기 영재에 의해서보다는 살아가면서 인생과 사회를 경험 하는 과정에서 우러나오는 예술이기도 하다. 1999년 5
월 이전의 영화진흥공사에서 영화진흥위원회로 재 창 립한 영화진흥위원회의 당시 위원장은 유인촌 전 문화 부장관의 형님이며 $\mathrm{MBC}$ 방송국의 프로듀서를 역임한 유길촌 위원장이었다. 영진위와 한국영화아카데미 동 문회 측에서는 2001년11월28일 '한국영화아카데미 발 전을 위한 종합 세미나'를 개최하고, 새로운 교육방향을 논의하게 된다. 영진위는 박기용 감독을 후임 책임교수 로 임명하였으며 새로운 한국영화아카데미를 위한 입 시전형과 제도의 개선, 편제의 개편, 장편 과정의 도입 등이 이뤄지게 된다.

\section{1. 애니메이션 아카데미의 설립과 영화아카데미 나이 제한 폐지}

극장용 애니메이션의 육성을 위하여, 한국애니메이 션 아카데미가 영화진흥공사에서 설립하게 되면서, 영 화진흥공사의 교육제도는 한국영화아카데미와 한국애 니메이션 아카데미로 확장된다. 98학년도에 첫 신입생 을 모집한 애니메이션 아카데미는 응시자격에 나이와 학력 제한을 없앤 반면에, 영화 아카데미는 같은 시기 에도 전문대 졸 이상과 만 30세 미만으로 나이를 제한 하였다. 영화 및 애니메이션 아카데미의 교육공간을 통 합하여 남산의 옛 서울예대 예술관으로 이전한 2001학 년도 입시전형에서는 영화아카데미의 나이 제한은 사 라졌다[48]. 영화 아카데미는 3학기제(18개월)로 연출 12 명, 촬영6명, 애니메이션 아카데미는 4학기제(2년)로 12 명을 모집하여 운영된다. 영화아카데미의 전형방법 은 1 차 영상구성작품(포트폴리오)과 학업계획서를 평 가하는 서류전형, 2 차 창의력, 기본소양 평가, 3 차 전문 성과 인성 면접 평가로 바뀌었으며, 영화 이외의 인접 예술 활동경력자에 대해서 면접 시 우대를 한다고 명시 하였다. 애니메이션 아카데미도 전형방식은 동일하였 다[49]. 이때 입학한 영화아카데미 신입생은 16 기가 되 며 학기당 실습비는 60 만원이다[50]. 이때의 경쟁률은 영화아카데미가 12.1 대 1 , 애니메이션 아카데미가 4.7대 1 이었다[51]. 한편 극장용 애니메이션 장편 <마리 이 야기>를 만든 이성강 감독은 2002년 한국영화아카데미 애니메이션 전공 전임교수로 임명되었다[52]. 


\section{2. 졸업생 감독들의 성과}

한편, 여성감독인 이정향 감독(35세 데뷔)은 1994년 에 쓴 자신의 시나리오 <미술관 옆 동물원>을 1998년 에 연출하여 90 만 명의 관객동원기록을 세운다[53]. 이 정향 감독이 2002년에 만든 <집으로>는 서울에서 32 개 스크린에서 상영되어, $1,576,943$ 여명의 관객을 동원하 는 기록을 세운다. 한편 <여고괴담> 1,2 편은 한국영화 아카데미 졸업생들이 연출하는 특색을 보인다. 직접 쓰 고 연출한 <여고괴담>의 박기형에 이어서, <여고괴담 두 번째 이야기>는 한국영화아카데미 13기 동기생인 김태용, 민규동의 공동연출로 데뷔작품이 된다[54]. 2000년 11월 9일에는 독일의 제49회 만하임-하이델베 르크 영화제에서 한국영화아카데미 특별전이 열려서 허진호 ,이재용 등의 작품 14편을 상영하였다[55]. 2001 년 제 54 회 깐느영화제 단편 본선경쟁부분인 시네 파운 데이션 부분에 영화아카데미 10 기 출신인 신동일의 <신성가족> $35 \mathrm{~mm}$ 단편영화가 영상원 졸업 작품 한편 과 더불어서 초청 상영되었다[56]. 영화아카데미를 졸 업한지 7년 만에 만든 단편영화로 거둔 성과이다. 신동 일 감독은 <반두비>(2009) 등 5 편의 장편영화를 연출 하였다. 아카데미 16 기 졸업 작품인 권일순의 “숨바꼭 질”은 2001년 8월 제58회 베니스영화제 단편경쟁부문 에 초청되었다[57].

한편 $\mathrm{IMF}$ 와 $\mathrm{CJ}$ 의 본격적인 영화산업 진출로, 한국영 화계의 세대교체가 급격히 이뤄지면서, 영화감독을 찾 는 수요가 증가하였다. 급기야, 영화 아카데미에 재학 중인 학생이 감독데뷔를 하는 현상이 발생하기도 하여, 재학생들의 동요와 영화아카데미 학사운영에 차질이 발생하기도 하였다. 동국대 연극영화학과를 졸업하고 영화 아카데미에 재학 중이며, 몇몇 단편 영화 연출을 하고, 스토리 보드 작가로 활약하던 모지은은 '좋은 사 람 있으면 소개시켜줘>로 26살의 여성감독으로 데뷔하 게 된다[58].

<도둑들>(2012), <타짜>(2006)를 연출한 최동훈 감 독은 서강대 국어국문학과를 나오고, 영화아카데미 15 기를 거친 후, 임상수 감독의 <눈물>(2000)의 조감독으 로 충무로에 들어왔는데, 데뷔작 <범죄의 재구 성>(2004)의 성공 후에 경향신문에 기고한 글에서, 한
국영화아카데미, 충무로 현장에 막내로 영화계 입문, 시 나리오 쓰기, 취직을 하여 생계를 도모한 뒤에 방법을 다시 생각하기 등 자신이 영화감독이 되기 위한 5 개년 계획의 5 가지 선택의 길에 대해서 언급하고, 영화아카 데미 졸업당시 주임교수였던 황규덕 감독이 하였다는 말로서 자신의 감독데뷔의 소회를 밝힌다. “해줄 말은 없다. 졸업하면 잘 살기 힘들거다. 다만, 정신병과 알코 올 중독증에 걸리진 말아라. 그럼 된다[59].” 한편 한겨 레 영화제작 학교와 한국영화아카데미를 나온 노동석 감독은 300 만원의 제작비를 가지고 디지털 장편 <마이 제너레이션>을 만들어, 신용불량과 청년실업으로 대표 되는 88만원 세대의 이야기를 화면에 담아냈다[60].

\section{3. 재교육 사업과 아시아 영화 아카데미의 시작, 외국인 졸업생 배출}

영화계는 또한 디지털시네마의 도래로 급격한 변화 를 맞이하게 되는데, 기존의 필름 작업을 하던 영화 인 력들의 디지털 $\mathrm{HD}$ 촬영장비에 대한 재교육의 필요성 이 대두되어서 한국영화아카데미에서 영화인 재교육사 업의 일환으로 ' $\mathrm{HD}$ 영화제작 이해과정'을 마련하였다 [61]. 이후, 자연스럽게 영화아카데미는 기존의 신진 영 화인 배출기능에 덧붙여서, 기존 영화인의 재교육 등, 영화진흥위원회의 교육기능을 전적으로 담당하게 되어 2004 년에는 장편영화 1편이상의 현직 프로듀서를 대상 으로 한 영화프로듀서 전문 과정을 개설하기도 하였다 [62].

디지털시네마의 확산을 위한 프로젝트의 일환이면서 한국영화아카데미 20주년을 기념하기 위한 <이공 꾭 共>이 제작되었다. <이공>은 5 분짜리 단편 20편으로 구성된 옴니버스 디지털 영화로, 봉준호, 허진호 등 한 국영화아카데미 출신 감독 20명이 연출하는 프로젝트 로 SKT가 4억 원의 제작비를 부담하고, 온라인으로는 SKT '준'을 통해서 2003년 12월에 공개되고, 12월19일 부터 열린 한국영화아카데미 20주년 영화제 개막작으 로 상영되었다[63]. 영화 주간지 씨네21은 영화 아카데 미 20년 특집 기사를 기획하여, 재학생의 열정이 한국 영화 르네상스의 싹이 되었다고 평가하면서 졸업생과 영화평론가 정성일이 바라보는 영화아카데미에 대한 
글을 게재하였다[64]. 2004년 9월말에는 남산동 교사에 서 마포구 서교동으로 한국영화아카데미를 이전하여 새로운 20년을 맞이한다. 한 신문기사는 영화아카데미 의 20년의 성과를 '한국영화 르네상스 일꾼 산실', '상업 적 작가주의', '현장중심의 실무교육'이라고 요약하였으 며, 앞으로 영화아카데미는 학제교육과 제작과정을 이 원화 하여, 장편영화를 제작하는 등 교육기관에서 나아 가서 제작소(프로덕션) 역할을 수행할 것이라고 밝혔다 [65]. 이 시기, 한국영화아카데미 박기용 원장의 구상은 교육중심 과정 1 년과 장편영화를 제작하는 제작연구과 정 1 년으로 학제의 이원화를 도입하는 것이다. 한편, 2004년의 한국영화아카데미는 연출 12 명, 촬영6명, 애니 메이션 12 명 정원을 두고, 2년4학기제로, 이론교육 외에, 1 차 디지털비디오(DV) 워크솝, 2 차 $16 \mathrm{~mm}$ 실습, 3 차 $35 \mathrm{~mm}$ 실습, 졸업 작품 워크샵 등의 제작중심 교육을 운영하여, 연출지망생인 경우, 2년간 5-30분 길이의 영 화 6 편을 연출하고, 제작진 참여 등을 통해서는 1 인당 20여 편의 영화제작과정을 거치게 된다. 2004년 현재 영화아카데미의 예산은 13 억 원으로 원장과 전임교수 3 명, 겸임교수 1 명 등 5 명의 교수진을 두고 있다. 비교를 위해서 1984 년의 영화아카데미 예산은 9000 만원으로 1 인당 교육비는 570여만 원이었는데, 2004년 현재도 1 인 당 교육비도 580여만 원으로 책정되어 있었다[66].

한편 <시월애>의 이현승 감독은 제 3 기 영화진흥위 원회 안정숙 위원장 체제에서 영진위 부위원장에 선출 된다. 영화현장의 의견을 반영하면서 관청가와의 가교 역할을 하는 임무를 맡게 된 것이다. 2011년에는 강한 섭, 조희문 위원장의 중도 하차 후에 수장이 없던 영화 진흥위원회에 현장영화인인 영화아카데미 1 기 출신의 김의석 감독이 위원장으로 선임되어 영화진흥위원회를 안정되게 이끌면서 현재 3 년의 임기 중 2 년을 채우고 있다[67]. 영화아카데미에 다니면서 영진위의 시스템에 친숙하고 직원과의 교류 등이 영화 현장과 정책집행기 관 즉 민관간의 업무를 추진하는 데에 도움이 되고 있 다고 보는 부분이다.

20 여년의 역사를 바탕으로 한 한국영화계에서의 기 여도와 해외영화제에서의 지명도는 베트남에 한국 자 본과 기술로 영화아카데미를 설립하려는 시도로도 이
어졌다. 즉 영화분야에서 세계적인 경쟁력을 갖춘 한국 의 지원으로 베트남에 체계적인 영상전문교육기관을 만들겠다는 시도였으나, (주)아이투아이(대표 정충국) 와 베트남의 닷상 미디어 간에 $\mathrm{MOU}$ 체결 외에는 실현 되지 않았다[68]. 그러나 한국영화의 강세를 바탕으로 아시아 지역에 공헌하려는 영화계의 움직임은 부산국 제영화제가 영화제 10 주년을 맞아 추진한 아시아 영화 아카데미(AFA)를 통해서 표출된다. 부산국제영화제 조직위와 한국 영화아카데미 그리고 부산의 동서대학 교가 함께 아시아 영화 아카데미를 개설하여, 매년 아 시아 지역 예비 영화인 28 명에게 21 일간 교육과 제작 기회를 제공하는 프로젝트가 가동된 것이다[69]. 한국 영화계의 국제화와 더불어서, 영화교육의 국제화가 이 뤄지는 단초가 형성되었다고 볼 수 있다. 한국영화아카 데미는 또한 '한국영화아카데미 아시아 장학 프로그램' 의 일환으로 중국의 조선족을 대상으로 중국동포 영화 교육 장학생을 선발하여 2006년 2월부터 한국영화아카 데미 교육과정으로 교육을 하기로 한다[70].

영화아카데미 첫 외국인 졸업생으로는 재중동포 방 예림과 옌볜TV 방송국 드라마 PD 출신인 강춘이 2007 년 2월에 배출되었다[71]. 2005년 부산국제영화제의 아 시아필름아카데미 프로그램에 참여한 후에 한국영화아 카데미에서 2 년간 영화를 공부한 인도 출신의 텐진 촉 레와 스리랑카에서 6 년간 촬영 일을 했던 칼링가 위타 나게는 2006년부터 시행된 부산국제영화제, 한국영화 아카데미, 동서대가 마련한 영화장학제도의 첫 번째 수 혜자이다[72]. 2004년 베를린 국제영화제 국제 앰네스 티 영화상을 수상한 이라크의 영화 <수선화>의 촬영감 독인 모하메드 자노 모하메드가 2007년부터 2009년까 지 한국영화아카데미의 아시아 장학프로그램(ASP)의 도움으로 한국에서 영화교육을 받았고 디지털 카메라 와 $3 \mathrm{D}$ 등 한국이 앞서가는 분야에서 기술을 습득하였 다[73].

\section{4. 전형과 전공 과정의 혁신과 실험}

영화아카데미가 처음 생길 무렵의 국내 연극영화학 과 5 개 학교, 이론중심의 교육, 연극과의 커리큘럼 분할, 카메라 장비 및 필름의 고비용 등의 문제들이 한국영화 
아카데미를 비교우위에 두게 하여, 영화 인재들을 빨아 들이는 블랙홀 역할을 하였으나, 영상원의 설립, 1999년 전후의 전국 대학의 영화 관련학과 증가, 컴퓨터와 디 지털 카메라만 있으면 디지털 영화제작이 가능해진 매 체의 민주화와 비용의 하락은 영화아카데미의 역할의 큰 변화를 요구하게 되었으며, 이에 따라서 학생들의 선발방식과 교육내용의 변화가 요구되었다. 합격생들 의 분포도 80 년대에는 영화학과 출신자와 일반대학출 신자가 평균적으로 각각 $50 \%$ 의 비율로 선발되었으나, 2005 년 현재, 입학자들은 대학 영화전공자 $30 \%$, 충무로 현장경험자 $30 \%$, 대학 영화 동아리나 사설 영화교육기 관 졸업자들이 $40 \%$ 를 차지하는 구성을 보여주고 있으 며[74], 대부분이 비디오를 이용한 영상물 제작의 경험 이 있는 환경이 되었다고 볼 수 있다. 그래서 당시 영화 아카데미 원장인 박기용 감독은 25기가 되는 2008학년 도부터는 기존의 1 차 전형의 '사회 문화 서술', '영화언 어 이해 서술’ 등 필기시험을 폐지하고, 포트폴리오 심 사로 변경하여, 실제 영상물에서의 표현능력을 중시하 였으며, 2 차 전형에서는 전공실기 및 필기를, 3 차에서 는 심층면접을 보는 형태로 전형을 치르게 된다[75]. 25 기에서는 영화연출 10 명, 촬영 8 명, 프로듀싱 8 명, 애니 메이션 연출 8 명을 선발한다. 또한 2006학년도부터는 기존의 2년 4 학기제에서, $1+1$ 즉 1 년 4 쿼터, 40 주의 학제 교육기간과 1 년의 장편영화제작과정으로 학제를 개편 하여, 1 년 학제교육과정을 거친 학생들 중에 장편 시나 리오 심사를 거쳐서 소수를 선발하여, 다시 1년간 디지 털 장편 영화 제작을 하는 형태로 변하게 된다. 제작연 구과정 1기의 교육기간은 2007년5월부터 2008년 4월까 지로 설정되었다. 이로써 프로덕션(영화제작소)으로의 영화아카데미의 기능이 강화되고 2009년부터 매년 디 지털 장편영화 3 편, 장편 애니메이션 1 편이 제작되고 4 명의 신인감독을 배출하는 시스템을 구축하게 된다. 편 당 제작비는 5 천만 원에서 9 천만 원이 들어가고, 애니 메이션의 경우는 조금 더 들어가기는 하지만, 지극히 초저예산으로 색깔 있는 영화가 만들어지고 있다. 장편 영화제작과정에는 또한 $\mathrm{CJ}$ 엔터테인먼트도 제작비를 일부 부담하고, $\mathrm{CGV}$ 극장에서 개봉하도록 도움을 제공 하고 있다. 2006년 1월에는 영화아카데미 프로듀싱 전
공 책임교수로 박성근 (주)진인사 전 공동대표를 임용 하였다[76].

\section{5. 다양한 배경의 출신 감독들}

나이제한과 학력제한을 없애고, 인접 예술 등 다양한 분야에 종사하던 사람들에 대한 특별전형의 도입, 포트 폴리오 심사 등 영화아카데미의 입학생 다변화 정책은 특이한 이력의 졸업생들을 많이 배출하게 된다. 6 천5백 만 원의 예산으로 디지털 장편 <신성일의 행방불명>을 만든 신재인 감독은 서울대 화학과에서 철학과로 전과 하고, 사법외무고시 1차 시험에 모두 합격한 뒤에 영화 를 하기로 결심하고 영화아카데미 17 기를 졸업하였다 [77]. 여성운동가로 활동하고 5살짜리 딸을 두고 있는 이숙경은 43세의 나이로 영화아카데미 22기로 졸업하 고, 2007년 장편제작연구과정(1기)을 통해서 3700만원 의 순제작비를 가지고 장편 <어떤 개인 날>을 만들었 고[78], 조희영은 조지타운대 박사과정을 수료한 경력 을 지니고 있다[79]. 손학규 전 경기도 지사의 차녀 손 원평도 영화아카데미 졸업생이다[80]. 한편 신동일의 <신성가족>이후 6년 만에 제60회 칸느 국제 영화제 시 네 파운데이션 부문에서 영화아카데미 졸업 작품인 $<$ 만남>이 3등상을 받았다. 이 작품은 경성대 연극영화 학과 출신이며 한국영화아카데미 22기를 마친 홍성훈 이 만들었다[81]. 김동령은 2004년 한국영화아카데미를 졸업한 뒤에 <아메리칸 앨리>(2008)과 <거미의 땅>(2012) 등 미군기지촌에 흘러들어온 러시아, 필리핀 등의 외국인 여성과 나이든 기지촌 출신 한국인 할머니 에 대한 장편 다큐멘터리 연출과 단편 극영화 작업을 지속하고 있다.

영화아카데미 9기인 성지혜는 프랑스 파리8대학에서 '장 외스타슈의 작품에 나타난 형식적 혁신의 원동력으 로서 성찰성에 대한 연구’로 박사 학위를 받고, 43살의 나이로 <여름이 가기 전에>로 데뷔하여, 국내 여성감 독 중에서 최고령 데뷔의 기록을 가지게 된다[82]. 영화 아카데미를 졸업한 지 14 년만의 일이다.

졸업생 중에 특이한 이력의 소지자로서 최두영을 들 수도 있다. 부산 동의대에서 화학을 전공하고 제약회사 에 다니다가, 1990 년에 한국영화아카데미 7 기 기술전공 
으로 들어온 최두영은 1991년 영화진흥공사(현 영화진 흥위원회의 전신)에 입사하여, 영화 필름의 색보정을 담당하는 colorist로 근무하다가 2001년 영진위를 그만 두고는 이윤택 원작의 <오구>의 제작과 촬영감독을 맡 는다. 2003년에는 재중동포감독 장률의 <당시>,<망 종>의 제작자겸 프로듀서로 활약하고, 2007년에는 <최 종병기 활>의 김한민 감독의 장편 감독 데뷔작 <극락 도 살인사건>을 제작하여 2 백 8 만여 명의 관객 동원을 기록한다[83]. 색보정, 촬영감독, 프로듀서, 제작자 등 영화관련 일을 두루 거친 최두영은 현재 세종대학교 영 화예술학과 교수로 있으면서 두 엔터테인먼트의 대표 를 맡고 있다. 영화아카데미 졸업생은 아니지만, 1993년 10 기생이 재학할 때, 이들의 학사업무를 담당하던 영화 진흥공사 직원인 김진성 감독은 학생들의 영화제작을 옆에서 지켜보다가 영화에 빠진 사례이다. 연세대 심리 학과 출신으로 1994 년 단편 <환생>을 만든 김진성은 2002년 <서프라이즈>로 장편 감독 데뷔를 하고, <거칠 마루>도 감독하였다.

\section{6. 독점과 폐쇄의 길드(Guild)의 기득권 종말}

우리나라 영화계는 1985년 7월3일 영화업 허가제에 서 등록제로 바뀌기 이전까지는 20개의 한국영화제작 사가 연간 2 편에서 5 편사이의 한국영화를 제작하면, 외 국영화 2편을 수입할 수 있는 수입쿼터제를 유지하였 다. 그래서 연간 100 여 편 이내의 한국영화가 만들어지 고 외국영화는 22편이 수입될 수 있었다[84]. 이러한 제 도는 한국영화계의 기업화라는 명분과 정부의 영화검 열 및 통제의 용이성에 의해서 추진되어 왔던 제도로 서, 기존의 영화인들에게는 다른 신진 경쟁자의 영화시 장 진출을 제한하여, 기득권을 인정하는 당근책으로 작 용하였다. 1960년 4.19혁명이 있던 해에는 55개의 영화 제작사가 총 92편의 영화를 제작한 반면에, 1961년 5.16 군사 정변이후, 1961년 9월30일 문교부 고시 제148호로 기존의 72 개 군소영화사를 제작실적 15 편이상의 제작 자를 인정하여 17 개사로 통합하게 된다[85]. 이러한 정 책은 1962년 1월20일 국가재건최고회의의 한국최초의 영화법 공포이후, 변화를 거치면서도 그 근간을 유지하 여, 1985년 영화업 등록제 시행까지 24년간 유지되었다.
외화수입 정책은 1949 년 1월20일부터는 공보처의 검열 을 통과하여 수입추천을 받은 영화에 한해 수입허가를 내주는 정책[86]을 시작으로 약간의 변동은 있지만 큰 틀은 유지하면서 1987년 7월1일 시행된 외국영화 수입 자유화와 시장개방까지 38년간 지속되었다. 극영화 203 편이 수입되었던 1959년의 수입영화 최고편수 기록 이 후, 1960년 수입된 극영화는 135편으로 문화영화를 포 함하여 208편이 수입되었었으나[87], 1972년 10월 유신 이후 1973년 2월16일에 개정된 제4차 영화법에 따라서, 한국영화 제작업이 허가제로 다시 돌아가고, 제작업과 수입업을 다시 일원화하여 한국영화의 제작실적, 수출 실적에 따라서 수입쿼터를 배정하였다. 그 결과 1973년 부터 1979년까지 국내 한국영화 제작사는 최저 12 개 (1973년), 최고 20개(1979년)를 유지하였고, 외국영화수 입편수는 연간 최저 25편 내외(1979년), 연간 최고 47편 (1973년)을 유지하였다. 한국영화보다는 외국영화의 흥 행수익률이 높은 상황에서 영화 제작사들은 수입쿼터 를 받기 위해 졸속으로 한국영화를 제작하는 등, 오히 려 한국영화의 퀼리티는 떨어졌고, 20 개의 영화사에 한 국영화시장의 독과점을 부여함으로써 오히려 신진인력 과 자본의 진출을 방해하고, 1960 년대 초 한국영화의 부흥기에 20대 초반의 나이로 영화감독이나 촬영감독 으로 데뷔한 영화인들이 30여 년간 기득권을 유지할 수 있었다. 정부의 영화에 대한 검열과 통제에 대한 당근 책이 바로 기존 업계의 기득권유지라는 반대급부였다. 이 시기 임권택 감독은 1962년 26세에 <두만강아 잘 있 거라>로 감독 데뷔하여, 2010년 <달빛 길어 올리기>까 지 48 년간 총 101 편의 영화를 연출하였으며, 서울대 기 계공학과 출신이며 1957년 26세의 나이로 <가거라 슬 픔이여>를 통해서 촬영감독으로 데뷔한 정일성 촬영감 독은 2006년 <천년학>까지 49년간 95편의 영화를 촬영 하였다. 이들이 한국영화를 대표하는 위대한 연출자이 며 촬영감독이라는 사실과 실력이 뛰어났기 때문에 제 작사가 이들을 많이 찾아서 당시 주어진 환경 하에서의 경쟁에서 살아남은 우수한 영화인이라는 점을 감안하 더라도, 평균적으로 1 년에 2 편의 작품을 할 수 있었던 여건에는 이러한 독과점의 영향을 무시할 수 없다. 정 인엽 감독은 1942년생으로 1965년 <성난 영웅들>로 감 
독데뷔하고 80년대 <애마부인> 시리즈로 유명하였던 감독인데 1997년까지 32년간 총 35편의 영화를 연출하 였다.

봉준호 감독의 경우 2000 년 <플란다스의 개>로 데뷔 하여 2013년까지 장편영화는 5편을 연출하여 평균 2.6 년 만에 영화 1편을 만들었고, 최동훈 감독은 2004년 데 뷔 후에 2013년까지 4편의 영화를 연출하였다. 영화아 카데미 1 기출신인 김의석 감독도 1992 년 <결혼 이야 기>로 데뷔 후 2002년까지 장편영화는 6편을 만들었다.

정부에 의한 통제와 더불어서, 한국영화감독협회, 촬 영감독협회, 조명감독협회, 극장협회 등 영화제작업계 의 일종의 동업조합인 길드 등을 통한 협회 인준이라는 제도를 통한 통제는 젊은 영화 인력들이 촬영분야의 경 우는 길게는 10 년간의 조수생활을 해야 하는 장벽으로 작용하였다.

\section{7. 신인감독 전성시대}

이러한 제한은 1987 년 미국의 압력에 의한 한국영화 시장 개방, 1985년 영화제작업 등록제와 시설기준 폐지 를 통한 독립프로덕션의 등장, 그리고 1999년 CJ의 CJ $\mathrm{CVG}$ 멀티플렉스를 통한 극장업 진출과 영화제작업 진 출을 겪으면서 사라지게 되고, 자연스럽게 새로운 젊은 영화인들로 세대교체가 이뤄지게 되었다. 새로이 등장 한 영화제작환경은 영화기획자 중심의 제작형태를 띄 게 되고, 그 결과, 감독의 예술이라는 영화에서 감독의 영향력의 약화와 신인감독의 대거양산이라는 현상을 가져왔다. 헤럴드 경제의 이형석 기자의 분석[88]에 따 르면, 2009 년의 경우 개봉된 한국영화 107 편 중 48 편이 신입감독의 데뷔작이며, 전체 개봉작 중의 $44.9 \%$ 가 신 인감독에 의해서 만들어져 신인감독에 대한 의존도가 높아졌다. 감독의 두 번째 영화인 경우는 23편(21.5\%), 3-4번째 연출작은 20편(18.7\%), 5편 이상을 만든 중견 감독의 연출작은 16 편(15\%)이었다. 총제작비 10 억 미 만 영화와 애니메이션을 제외한 상업 장편영화 72 편만 을 놓고 보았을 때도 감독 데뷔작인 28편(38.9\%), 2번째 영화 16편(22.2\%), 3-4번째 영화 16편(22.9\%), 5 작품이 상인 감독의 영화 12 편(16.7\%)이었다. 감독이 데뷔작 이후 2009년에 두 번째 작품을 만들기 까지는 평균적으
로 3.75년이 소요되고 짧게는 1 년 길게는 9년 만에 두 번째 작품을 만들기도 하였다.

전국에 60 여개에 이르는 영화영상 관련학과와 한국 영화아카데미 등에서 매년 배출되는 졸업생들이 어렵 게 감독이 되더라도, 다음 작품을 하기는 아주 힘들다 는 것이다. 너무나 치열한 경쟁시장이기에 신인감독의 생존율은 지극히 낮으며, 신인감독에 대한 의존도가 높 아서 신인감독의 경험부족과 완성도 하락 등이 한국영 화의 위기를 낳을 수도 있다는 부작용도 드러나기도 하 고 있다. 영화감독의 1 회성 소모품 화라고도 할 수 있 다. 2009년 흥행 톱10에 든 한국영화는 평균적으로 감 독들의 3 번째 연출작이 많았다. 즉 감독의 숙련도가 중 요하다는 점을 보여주고 있다. 신인감독의 선호는 제작 사 입장에서 통제하기 편하다는 점과 높지 않은 연출 료, 젊은 관객들의 트렌드를 반영할 수 있다는 점, 신선 한 아이디어, 감독 데뷔를 위해서 한 작품을 오랫동안 준비하였다는 점 등이 장점이나 검증하기 쉽지 않은 능 력과 경험부족이라는 단점을 갖는다. 아무리 단편 영화 나 독립 장편영화에서 실력을 드러냈다고 하더라도, 그 것이 반드시 상업영화에서의 성공으로 이어지지는 않 기 때문이다. 한편, 감독의 신선한 아이디어와 도전정신 을 숙련된 스텝이 충실히 살려낸다면 성공으로 이어질 가능성이 높으며, 할리우드의 경우도 이런 전략을 많이 취하여, 하이틴물이나, 호러 물 등에서는 특히 신인감독 을 많이 찾아볼 수 있다. 1999년부터 시작된 신인감독 의 데뷔 러시는 이전까지의 진입장벽과 경쟁에 대한 제 약이 사라진 환경에서는 앞으로도 지속될 현상이라고 본다. 한국영화아카데미의 경우도, 장편제작연구과정을 통해서 매년 4 명의 신인 감독을 배출하는 시스템을 구 축하였으나, 앞으로의 과제는 이들을 비롯한 졸업생중 의 신인감독들이 두 번째, 세 번째 작품을 연출하면서 한국영화계의 중견감독으로 성장할 수 있는가 하는 문 제이다. 이러한 과제를 달성하기 위해서는 당장의 영화 제작을 잘 할 수 있는 우수한 인재와 더불어서, 가능성 을 보고 다양한 인재를 선발하고, 교육을 통해서 성장 할 수 있도록 장기적 관점에서의 전망에 바탕을 둔 접 근이 필요하다.

한편, 2001년에 시련을 겪으면서 출범한 한국영화아 
카데미 박기용 감독체제는 커리큘럼과 선발 방식에서 새로운 혁신을 이뤄내면서 시대의 요구에 부흥하는 모 습을 보여, 한국영화에 관심 있는 인사들로부터 긍정적 평가를 받게 된다. 이러한 분위기는 케이블 위성 TV 유 료 영화채널 캐치온에서 한국 영화감독 사관학교로 평 가받는 한국영화아카데미를 집중 조명하는 다큐멘터리 2 부작 '한국영화아카데미의 도전'을 제작 방영하고, 미 국의 $\mathrm{AFI}$, 프랑스의 국립영화학교 페미스 등 과의 비교 연구와 출신 감독들의 소회를 보여주었다. 이 기획에 맞춰서 캐치온은 봉준호, 허진호, 이재용 등의 아카데미 졸업 단편영화 10편도 방영하였다[89]. 2008년 재정부 가 발표한 '미래 산업 청년리더 10만 명 양성계획'에서 도 문화부는 기존의 한국영화아카데미 운영을 통해서 2009년에 184명, 전체 1천235명의 우수 인력을 양성하 겠다고 밝히기도 하였다[90]. 설립25주년이 되는 2009 년에는 장편제작연구과정 1 기에서 만들어진 3편의 장 편 극영화와 1 편의 장편 극장 애니메이션 중에서, 백승 빈 감독의<장례식의 멤버>가 제 59 회 베를린국제영화 제에 초청되었고[91], 이숙경 감독의 <어떤 개인 날>은 베를린국제영화제 넷팩상을 수상하였다[92]. 한국영화 아카데미의 외국교육교재 번역 발간 사업으로는 로스 로웰의 '영상조명 강의' 등 4권의 영화인 교육교재를 번 역해 출간하는 등, 영화관련 저역서 출판 사업도 추진 하였다[93].

\section{8. 다시 닥친 위기}

하지만, 이러한 행진은 이명박 정부 들어서서 강한섭 위원장에 이어서 2009년 9월, 두 번째 영진위 위원장을 맡은 조희문 체제에서 브레이크가 걸린다. 조희문 위원 장은 유인촌 문화부 장관에게 행한 업무보고를 통해서 영화 아카데미 기능 개편 등의 영진위 개혁안을 발표하 였고[94], 이미 10월30일 자로 영진위 조직개편을 통해 서, 기존에 사무국에서 독립적인 한국영화아카데미의 위치를 사무국 산하로 두고, 원장의 직급을 기존의 임 원급에서 부서 부장급(2급)으로 조정한다. 그리고 3 명 의 책임교수의 계약 기간도 기존의 2 년에서 1 년으로 축 소했다[95]. 추후로는 '영화아카데미' 라는 명칭도 '영화 인력 개발지원 센터’로 변경하고 원래의 설립 목적인
신규 영화인력 양성은 폐지하고 영화인 재교육사업과 영화인 근로환경개선사업에 집중하는 방향으로 개편하 고자 추진한다. 지난 25년간 한국영화계에서 성과를 발 휘해온 신진인력 양성 기능을 민간과 공공기능의 중복 이라는 이유로, 즉, 전국에 많은 영화 관련학과가 대학 에 설치되어 있으며, 한국예술종합학교 영상원과의 중 복이 아니냐는 비판에 거둬드리려 하는 것이었다[96]. 지난 25년간의 성과를 바탕으로 한국영화정책의 모범 사례로 삼아, 주변 아시안 국가를 망라하는 국제영화학 교로서의 기능을 수행할 수 있을 정도로 성공모델로 삼 을 수도 있는 지나온 역사를 그낭 버리고자 하는 것이 었다. 아시아 영화학교로의 확대 개편에 대해서는 이명 박 정부가 임명한 전임 영진위 강한섭 위원장도 제안하 였던 사항이다[97]. 강한섭 위원장은 노무현 정부 때 확 정된 영진위와 한국영화아카데미의 부산이전에 미온적 이며 반대하는 듯 한 태도를 보여 부산지역의 반발을 불러온다[98].

이러한 조치의 배경에는 이명박 대통령의 대선기간 동안 문화정책을 다룬 문화미래포럼의 주장이 담겨있 다. 문화미래포럼이 주최한 '새 정부 문화예술 정책 과 제- 문화예술기구 및 단체 개혁방안' 심포지엄[99]에서 조희문[100]은 '이념과 선동의 레드카펫을 걷다: 한국영 화정책 10 년의 돌격’을 통해서 김대중, 노무현 정부를 거치면서 영화진흥위원회가 영화를 통한 문화혁명을 꾀한다고 보았고. 송낙원[101]은 영진위의 부산이전 정 책이 오류라고 지적한다. 한국영화아카데미의 폐지 혹 은 기능 개편은 김종국[102]이 '해체와 재구성을 통한 영화진흥위원회 개혁방안'에서 주장한다. 김종국은 자 신이 2007년 10월 24 일, “참여정부와 영화정책, 비판적 대안 모색” 심포지엄(문화미래포럼 주최)에서 발표한 “한국영화진흥제도 및 정책의 문제”와 2007년11월20일, "한국영화의 새로운 도약을 위한 영화인 대토론회” (사 단법인 한국영화인원로회의 주최)에서 발표한 "영화계 현장인력 처우개선을 위한 신구 영화인연대 모색”을 발 전시킨 글의 연장선상에서 일관된 주장을 폈다. 김종국 [103]은 국립영화학교인 영상원의 존재, 국내 많은 대학 에서의 영화학과 설치, 해외유학 영화 인력의 다수 등 장, 외국 영화학교의 한국 진출 움직임 등을 들어서 한 
국영화아카데미의 본래 설립취지는 무의미해졌다고 보 고 해체를 주장한다. 해체를 반대하는 세력은 현재 영 화계의 주류로 자리 잡은 졸업생들의 전통에 대한 수구 적 태도이며 기득권 유지를 위한 의도라고 보았다. 영 화계의 보수 흐름을 대변하는 정인엽 영화감독협회 이 사장도 영상원과 중복되는 영화아카데미를 폐지하여야 한다고 주장한다[104]. 김종국은 영진위가 진행하는 인 력양성부문의 모든 예산을 영화아카데미의 신진영화인 력 양성 비용으로 간주하고 1999년부터 2006년까지 85 억 원을 사용하여, 전체예산중에서 $3.7 \%$ 를 차지한다고 주장한다. 그러나 실제 같은 기간 인력양성비용 중 한 국영화아카데미 정규교육에 쓰인 예산은 8년간 70 억6 천7백8십5만1천원으로, 연간으로 계산 한다면 연평균 8 억8천3백4십8만1천여원에 불과하다. 이점은 같은 책의 조희문의 글에서 인용한 영진위 사업내역에서도 확인 이 가능한 점이다[105].

조희문 영진위 위원장은 미디어 센터 지원 사업을 공 모제로 전환한 뒤에 설립 한 달이 안 된 (사)시민영상문 화기구를 선정한다. 이 법인의 사무총장은 숭실대 문예 창작학과 교수이며 축구평론가인 장원재이며 김종국 홍익대 겸임교수가 미디어센터 소장 직을 맡을 예정이 었다. 미디어 센터는 퍼블릭 엑세스와 지역 미디어센터 설립 운동을 주도하던 한국독립영화협회가 2000년 영 진위에 사업제안을 하고, 2002년 영진위와 위탁계약을 맺고 2010년1월31일까지 운영해오던 미디액트이고 2009년 감사원과 문체부의 감사에서도 운영을 잘하고 있다는 평가를 받았다[106].

영진위의 새로운 독립영화전용관 사업자로 한국다 양성 영화발전협의회(대표 허은)을 선정하고 극장 시네 마루를 운영하고자 하는 데에 반발하여 <워낭소리>의 이충렬 감독, <똥파리>의 양익준 감독 등 독립영화 감 독 155 인이 자신들의 작품이 시네마루에서 상영되는 것을 반대하고 2010년 2월17일 보이콧트를 선언하자 [107], 영진위는 한국영화아카데미의 장편제작연구과정 의 장편 영화와 단편영화를 상영하고 이에 대해서 작품 을 만든 감독들은 상영에 강력히 반대하며 씨네마루 앞 에서 1 인 시위를 펼쳤다[108]. 한국영화아카데미 동문 들은 학교 정상화를 촉구하는 비상대책위원회를 조직
한다[109]. 독립영화전용관, 미디어센터, 시네마테크, 그 리고 한국영화아카데미의 문제에 대해서 영화인 회의 와 여성영화인모임, 영화감독조합, 미술감독조합, 한국 영화제작가협회, 독립영화협회는 한국영화단체연대회 의를 구성하고 2010년 2월24일 사태의 정상화를 촉구 하는 성명서를 발표하나 조희문 영진위 위원장은 영화 계 일부의 반발이라고 평가한다[110]. 영화단체연대회 의는 최문순 국회의원의 후원을 받아서 국회 의원회관 에서 "영진위 정상화를 위하여: 영진위가 가야 할 길을 묻다” 토론회를 3월9일 개최하였다. 이 자리에서 원용 진 서강대 커뮤니케이션 학부 교수는 영상미디어센터 운영주체를 친척이라는 이유로 당첨시켰다고 비판하였 고, 최현용 영화단체연대회의 사무처장은 작금의 사태 는 영화-문화정책의 주요기준을 '이념-경제적 차원'으 로 전도시킨 결과라고 보았고 한국영화제작가협회 차 승재 회장은 현장영화인이 직면하는 것이 한국영화의 현실이라면, 독립영화전용과, 미디어 센터, 한국영화아 카데미는 한국영화의 미래라고 자리매김하고, 영화인 들이 정권이 바뀔 때마다 파란 물을 들이고, 빨간 물을 들이고 할 수는 없다면서 그리 정파적이지 않은 영화인 들에 대해 강한섭-조희문 영진위 위원장 체제가 대립 각을 세우고 있다고 분석하였다. 오동진 영화평론가는 한국영화아카데미가 신입생을 받지 못하는 것은 국가 기능이 마비되었다고도 볼 수 있다고 하였다[111]. 봉준 호, 정윤철, 변영주, 김조광수 감독과 차승재 대표를 포 함하여 1892 명의 영화인들이 '영진위 정상화 촉구' 선언 문을 발표하고 사실상의 현 조희문 영진위 위원장 체제 에 대한 불신임을 선언하였고[112], 도종환 시인 등 문 화예술인들도 영진위 정상화를 촉구하였다[113]. 영상 미디어센터, 독립영화관, 그리고 부산국제영화제 등 영 화제에 대한 지원 축소 등의 일련의 움직임에 대해서 도 넘은 좌파 청산이라는 비판이 제기되기도 하였고 결 국은 정치에 무관심한 사람들조차도 불신임을 나타내 기도 하였다[114]. 1999년 이후에 급격히 확대된 영화계 의 세대교체를 뉴라이트 문화미래 포럼은 단순히 좌우 대립으로 평가하는 오류를 범한 것이다[115]. 


\section{9. 한국영화아카데미 위상과 역할에 대한 평가}

한편 한국영화아카데미 총동문회에서는 영화아카데 미 정상화를 촉구하는 영화제와 '한국영화아카데미, 어 떻게 할 것인가?' 라는 토론회를 3월18일 서울아트시네 마에서 개최한다. 이 자리에서 조희문 위원장은 한국영 화아카데미가 너무 엘리트 화되었고 영화아카데미는 학교가 아니라면서 재교육중심으로 재편되어야 한다고 주장하고 이것이 영화아카데미를 잔류시키는 데에 대 한 기획재정부가 요구한 사안임을 밝혔다. 영화 등 콘 텐츠 산업은 결국 소수의 엘리트에 의해서 이끌어진다 고 본다. 누구나 노래방에서 노래를 부르고, 수많은 가 수가 있지만, 전 세계적인 히트를 낳은 가수는 싸이 한 명이다. 연간 만들어지는 150 여 편의 영화중에 천만관 객을 달성하는 영화는 1-2편에 불과하며, 세계적인 영 화제에서 수상하는 영화도 1-2편에 불과하다. 영화아카 데미가 엘리트 화되었다는 비판은 결국 권력화, 마피아 화되었다는 비판이라고 볼 수 있다. 원로감독인 하명중 은 영화에는 인재가 중요한데 그 인재를 키우기 위해 영화아카데미를 만들어 26 년이 지난 지금 영진위보다 더 큰 존재가 되었다고 평가하고 영화아카데미는 한국 영화계의 것이라고 하였다. 이 자리에서는 한국예술종 합학교 영상원의 전문사 과정 15 명으로는 영화를 하려 는 지원자의 수요를 충족시키지 못하며 그럴 경우에는 더 많은 인력들이 해외유학을 선택하거나 영화를 포기 하는 현상이 나올 것이며, 일본이나 홍콩의 영화계가 10 년 이상 침체기를 겪고 있는 것도 체계적인 영화교육 이 없어서 그렇다는 평가도 나왔다[116]. 테라와키 켄 교토조형예술대학 영화과 교수는 영상메시지를 통해 서, 한국영화아카데미는 세계적인 모델이며 아시아와 세계영화의 재산이라고 평가하면서, 자신이 만약 일본 영화만을 생각하는 국수주의 극우라면 한국에서 영화 아카데미를 폐지한다는 것에 만세를 부를 것이라고 반 어적으로 부당함을 피력하였다. 정성일 영화평론가는 한국영화아카데미의 장점으로 '저렴한 등록금', ' 1 년이 라는 짧은 교육기간에 집중적인 교육' '장편연구과정을 통한 데뷔의 가능성', '학력제한과 나이 제한이 없음'을 들면서 차제에 정치적 외풍에 자유롭기 위하여, 독립된 기관으로 거듭나야 한다고 주장하였다[117]. 영화를 전
공하지 않은 비전공자들이 자신의 전공지식과 인문학 적 배경을 바탕으로 유명감독들이 되었으며 해외에서 도 벤치마킹하려고 하고 있다는 평가도 있었다[118]. 당 시 민주당 최문순 의원은 영화 및 비디오물의 진흥에 관한 법률(영비법)에 영진위가 한국영화 진흥 및 영화 산업 육성 등을 위해 조사, 연구, 교육을 한다는 규정은 있지만 영화아카데미에 대한 규정은 없다면서 교육기 관 설치 근거 조항 신설 등 법적인 보완장치가 필요하 다고 주장하였다[119]. 2012년 5월 발효된 방송법의 제 90 조의 2에서는 시청자 미디어센터에 대한 법적 근거 를 명시하고 있다. 방송위원회는 시청자의 방송참여와 권익증진을 위해 시청자미디어센터를 두도록 하였으 며, 그 경비는 방송통신발전기금에서 지원하도록 명시 하고 있다[120].

\section{0. 새로운 시작}

영화아카데미를 둘러싼 논란은 문화부 유인촌 장관 이 임명 14개월 만에 조희문 영진위 위원장을 2010년11 월8일 해임하면서 일단 가라앉게 된다[121]. 문화부는 후임으로 전주영상위원장이며 한국영화아카데미 연출 전공 책임교수를 역임하고, 영진위 부위원장으로 조희 문의 해임이후 위원장 직무대행을 맡고 있던 김의석 감 독을 임기 3 년의 위원장으로 임명한다[122]. 영진위는 2011년 1월19일에는 영화아카데미 책임교수진으로 영 화연출의 김태균 감독, 애니메이션의 이성강 감독, 촬영 의 이종국 감독, 프로듀싱의 이지승 감독, 시나리오의 박헌수 감독을 채용한다[123]. 2009년 12월말 박기용 원 장의 퇴임 이후 공석이었던 한국영화아카데미 원장에 는 2010년 3월 15 일 공모절차를 시작하여, 임기 2 년의 2 급 대우로 장현수 감독을 임명하나[124] 중도 하차하게 되고, 최익환 감독이 후임 원장으로 임명된다[125]. 최 익환 체제의 한국영화아카데미는 그동안에 축적된 단 편영화와 장편영화를 LG U+와 KT Olleh의 IPTV를 통 해서 VOD 서비스를 실시하고 있으며, 성공적인 부산 이전을 추진 중이며, 2013년 정규과정과 제작연구과정 의 이원화 학제로 개편(1+1년제)하고, 비용 대비 효율 이 낮았던 시나리오 전공과 프로듀싱 전공을 폐지하여, 연출전공자가 재학 중 시나리오와 프로듀싱을 경험해 
볼 수 있도록 일종의 싱어 송 라이터, 향후 연출 이외의 분야에 진출하더라도 영화연출을 이해하는 멀티 플레 이어 영화인력 양성을 목표로 선택과 집중을 시행하였다.

\section{IV. 맺는말}

국민소득 4천불 시대인 1984년 설치되어 국민소득 2 만 불 시대인 2013년 30주년을 맞은 한국영화아카데미 에 대한 관련 콘텐츠, 예술분야의 평가는 긍정적이다. 할리우드 직배영화의 먹구름 속에서 영화진흥위원회가 묵묵히 지원한 한국영화아카데미가 현재의 빛을 발하 고 있듯이 한국 산업에서 '소프트웨어(SW) 마에스트로 과정 멘토단'이 'SW판 영화아카데미'가 되기를 기원하 기도 하고[126], NHN도 소프트웨어 인력 전문양성기관 을 만들어서 '제2의 봉준호, 최동훈' 등 미래형 인재를 키우고자한다[127]. 한국뮤지컬협회는 뮤지컬 아카데미 의 롤 모델을 한국영화아카데미에서 찾자는 주장이 제 기되기도 하였다[128]. 대중음악계에서도 대중음악진흥 위원회 설립을 통해 한국영화아카데미처럼 적절한 지 원을 통해서 뛰어난 인력을 배출하는 효율적인 시스템 을 구축하여야 한다는 의견이 나왔다[129]. 앞으로 다음 30 년간 이런 긍정적 평가를 이어가기 위해서는 시대가 요구하고 영화계가 요구하는 것들에 적극 반응하여 항 상 혁신에 앞서 나아가야 할 것이다. 우선 부산이전을 통해서, 영화아카데미가 처음 설치되었을 때 한국영화 계의 요구와 비슷한 부산지역 영화산업 활성화를 이끌 어야 할 것이며, 1980 년대 초반 우리나라처럼, 1 년에 외 국영화를 20여 편으로 제한하고 있는 중국 영화시장의 스크린 쿼터를 뚫을 수 있는 중국에서 합작영화를 제작 할 수 있는 영화 인력을 양성하여, 향후 중국의 스크린 쿼터가 한국과 유사할 시점을 대비하여야 할 것이며, 미국시장 등 좁은 한국에서의 정체된 영화수익을 외부 에서 찾을 수 있는 국제화된 인력을 양성하여야 할 것 이다. 또한 아시아와 세계에 지한파, 한국영화에 우호적 인 영화인재를 양성하기 위한 외국인 유학생을 적극 유 치하여 세계적인 영화학교로 거듭날 수 있도록 하여야 할 것이다. 이렇게 하기 위해서는 정권의 변화에도 흔
들림 없이 나아갈 수 있는 기반이 조성되어야 한다. 그 리고 이전까지는 시설과 장비의 우위에서 뛰어난 학생 들이 자연히 몰려들었었다면, 이제부터는 영상원과 대 학 등 다른 교육기관과 경쟁적으로 우수 인재를 선발하 고, 뛰어난 교육을 통해 이들을 성장시키고, 영화 현장 에 성공적으로 안착할 수 있도록 졸업 후 진로에 대한 적극적인 지도를 기울여야 할 것이다. 전공자와 비전공 자, 흥행영화지향과 예술영화지향, 다큐멘터리 등 영상 문화 전반을 아우르는 다양한 스펙트럼의 인재들을 배 출하는 것이 한국영화문화의 성장에도 중요한 과제이 다. 연간 1-2편의 영화흥행이 천만관객을 가져가는 승 자독식의 경쟁이 치열한 영화흥행의 속성에서, 다양성 의 확보와 패자부활전이 허락되기 위해서는 영화인재 의 배출창구도 다양하여야 할 것이다. 중앙대 영화학과 학부 출신, <범죄와의 전쟁>의 윤종빈 감독, 영상원 전 문사 출신, <황해>의 나홍진 감독, 한국영화아카데미 출신인 <설국열차>, <괴물>의 봉준호 감독, 〈타짜>, <도둑들>의 최동훈 감독 등의 경우처럼 다양한 교육 기관에서 그리고 독립영화계, 영화제, 시나리오 공모전, 등 다양한 창구를 통해서 영화 엘리트 인재들이 발굴된 다면 한국영화의 미래는 밝다고 볼 수 있다.

한국영화사에서의 한국영화아카데미의 위치에 대한 연구는 정성적, 정량적 두 방향 모두에서 진행할 수 있 다. 본 연구는 객관적인 서술을 위해서, 졸업생이나 영 화종사자를 중심으로 한 인터뷰 기법 보다는 주관성을 어느 정도 배제하고, 그 당시 중요성에 의해서 신문기 사가 나왔음을 전제로 한 문헌연구를 진행하였다. 이것 이 본 연구의 목적이며 한계이다. 향후, 정량적 연구로 서, 영화 아카데미에 들어간 예산, 한국영화의 점유율, 지원율, 감독 데뷔 비율, 영화계 종사 비율, 감독 데뷔까 지 걸리는 기간, 출신 감독들의 관객 동원 비율, 영화제 수상실적, 영상원 및 국내외 대학 영화학과와의 비교 등을 수행할 수 있으며, 졸업생과 영화계 종사자 등을 대상으로 한 인터뷰 및 설문조사를 통한 질적 연구의 진행도 가능하다. 


\section{참 고 문 헌}

[1] 영진위, 2013년 영화발전기금 운용계획, p.10, 2013.

[2] 김정호, 부산 이전 한국영화아카데미 발전 방안 보고서, 영진위, pp.16-20, 2012.

[3] 경향신문, “흥행감독은 성적순이 아니잖아요”, 2010.12.20.

[4] 경향신문, "문공부, 전문 인력 양성 질 높이게 영 화아카데미 설립”, 1983.10.27.

[5] 동아일보, “영화 아카데미 오는 3월 설립”, 1984.1.16.

[6] 경향신문, "한국영화복지 재단 이달 발족-영진공, 감독 등 교육 아카데미도 설립”, 1984.1.14.

[7] 동아일보, "1984학년도 한국영화아카데미 신입생 모집 광고", 1984.1.27.

[8] 경향신문, "영화아카데미 신입생 최종합격자 12 명 발표”, 1984.2.28.

[9] 경향신문, " 1985 학년도 한국영화아카데미 신입생 모집 광고", 1985.2.19.

[10] 매일경제, "과감한 투자로 방화 살린다-어우동 히트 계기로 본 한국영화 현주소”, 1985.10.19.

[11] 동아일보, "1986학년도 한국영화아카데미 신입 생 모집 광고”, 1986.1.27.

[12] 매일경제, "영화계 진흥에 새 활력소-문공부 발 전시책 발표 후의 움직임”, 1986.4.12.

[13] 매일경제, "개봉관 흥행제고 안간힘-하루 관객 4 백 명 밑돌아 큰 시름, 입장료 인하, 명작 조기상 영 모색”, 1987.4.1.

[14] 경향신문, "1987학년도 한국영화아카데미 신입 생 모집 광고”, 1987.1.23.

[15]경향신문, "영화아카데미 신입생 선발 남14, 여2 명- 1년간 교육”, 1987.3.17

[16] 경향신문, "한국영화아카데미 영진공서 작품발 표”, 1988.11.15.

[17] 한겨레, “신진 시나리오 작가 등장 많아-표현영 역 확대 힘입어 젊은 감독과 합류”, 1988.12.25. [18] 동아일보, "1989학년도 한국영화아카데미 신입
생 모집 광고”, 1989.1.20.

[19] 한겨레, "80년대 영화세대 독립제작 본격화-영 화공장 서울, 파랑새, 새빛, 물결 등”, 1989.11.11. [20] 매일경제, “활동 두드러진 젊은 영화인들 영화계 에 신선한 자극-수련거친 10-20명이 전 작업 공 동참여, 기존의 제작태도 탈피 뉴시네마 표방”, 1989.12.6.

[21] 한겨레, “제작비 지원이 영화진흥 핵심, 영화인 여론조사 종합촬영소 필요 84\%”, 1989.10.7.

[22] 한겨레, "예비영화인들 교육현장 갈등 화면에중앙대, 경희대 모임 소형영화 2편 선보여", 1989.11.11.

[23] 한겨레, “영화아카데미 졸업 작품 검열 말썽”, 1989.11.22.

[24] 동아일보, “임양 방북다룬 영화제작 논란”, 1989.11.22.

[25] 한겨레, “영화아카데미 작품검열 비난”, 1989.12.5.

[26] 한겨레, "임수경씨 가족 다룬 영화 선봬- 1 회 독 립영화제 예술극장 한마당서”, 1990.3.24.

[27] 경향신문, "영화의 30대 감독 대거 등장-국내외 서 수업마치고 속속 메가폰”, 1992.6.11.

[28] 경향신문, "외화 파죽지세 한국영화 주눅-영화 산업 올 한해 명암", 1992.12.26.

[29] 경향신문, "독일 국제단편영화제 <호모 비디오 쿠스>진출", 1992.4.12.

[30] 경향신문, “<호모 비디오쿠스>감독한 이재용 씨”, 1993.2.12.

[31] 동아일보, "1993학년도 한국영화아카데미 신입 생 모집 광고”, 1993.2.11.

[32] 동아일보, “영상아카데미 신축 기공-영화인재 양성요람, 95년 완공”, 1993.12.17.

[33] 매일경제, "영상산업 범정부차원 진흥책 마련키 로”, 1994.10.21.

[34] 한겨레, "국내 첫 대학과정 영화학교 '영상원' 개 원", 1995.3.10.

[35] 경향신문, "창고 속 영상보물 먼지 털고 대중 곁 으로-단편영화 비디오 출사 줄이어”, 1995.11.4. 
[36] 경향신문, “단편영화 감상기회 늘어”, 1996.6.15.

[37] 동아일보, "DVD 만나 르네상스, 독립영화 vs 예 술영화”, 2003.2.18.

[38] 경향신문, “영화아카데미 원생모집”, 1996.3.5.

[39] 한겨레, “영화아카데미 합격자 발표”, 1996.3.30.

[40] 한겨레, “국내 첫 조명 아카데미 개설”, 1996.4.19.

[41] 경향신문, “전문 아카데미에 대졸자들이 몰린 다", 1996.4.23.

[42] 경향신문, “충무로 등용문 영화학교 인기”, 1996.7.20.

[43] 한겨레, “외국영화학교 분교 설립 바람”, 1998.1.16.

[44] 한겨레, “신세대 촬영감독 충무로 반란”, 1996.7.13.

[45] 씨네21, 전국영화영상학과 입시가이드 2013(씨 네21 882호 별책부록), 2012.12.4.

[46] http://www.ohmynews.com/nws_web/view/ at_pg.aspx?CNTN_CD $=$ A0000050518

[47] 김창유, 김세훈 외, 국내 영상 실무 전문인력 양 성을 위한 전문 교육 모델 및 지원 정책에 대한 연구, 문화관광부, pp.186-201, 1999.11.

[48] 경향신문, "한국영화 애니메이션예술아카데미 신입생 모집 광고”, 1999.12.9.

[49] 한겨레, "한국 영화 애니메이션 아카데미 신입생 모집 광고”, 1998.12.19.

[50] 매일경제, “영화아카데미 원서접수”, 1999.1.5.

[51] 연합뉴스, "영화 및 애니메이션 아카데미 합격자 발표", 1999.2.13.

[52] 연합뉴스, "영화 아카데미 전임교수에 '마리 .....'. 이성강”, 2002.9.3.

[53] 동아일보, "충무로 여성 4 인방 할리우드 눌렀다", 1999.2.1.

[54] 동아일보, "여고괴담 두 번째 이야기, 동성애 등 도발적 내용 담아”, 1999.12.24.

[55] 한국경제, “한국영화아카데미 특별전”, 2000.9.19.

[56] 국민일보, “제54회 칸 국제영화제 초청받은 한국 영화 2편”, 2001.5.9.
[57] 한국일보, "베니스 영화제 권일순 감독 ‘숨바꼭 질' 초청”, 2001.7.27.

[58] 연합뉴스, '<인터뷰> '좋은 사람 …...'의 여성 감독 모지은씨", 2002.4.3.

[59] 경향신문, “[그루터기] 영화인생”, 2004.11.04.

[60] 조이뉴스 24 , “노동석 감독, '300만원에 저당 잡힌 청춘”, 2004.11.19.

[61] 연합뉴스, "영화아카데미, $\mathrm{HD}$ 영화강좌 신설", 2003.9.10.

[62] 연합뉴스, "영화아카데미 프로듀서 전문 과정 개 설”, 2004.10.17.

[63] 씨네21, 영화아카데미 20년, 씨네21, 426호, 2003.11.7.

[64] 경향신문, “영화계 덮친 디지털 바람”, 2003.10.30.

[65] 헤럴드 경제, "[20돌 맞은 한국영화아카데미] 예 술 흥행성 겸비 ‘월메이드 영화'주도”, 2004.8.23.

[66] 위의 글

[67] http://star.ohmynews.com/NWS_Web/OhmyStar /at_pg.aspx?CNTN_CD=A0001851599\&CMPT_ $\mathrm{CD}=\mathrm{P} 0001$

[68] 연합뉴스, "<해외 한류> 베트남에 한국영화 아 카데미 설립 추진”, 2005.2.5.

[69] 연합뉴스, "PIFF 10 주년 기념 영화아카데미 개 설”, 2005.6.7.

[70] 연합뉴스, "영진위, 중 조선족 영화교육 장학생 선발”, 2005.6.20.

[71] 연합뉴스, "<인터뷰> 영화아카데미 첫 외국인 졸업생 강춘", 2007.2.15, 스포츠 경향, "[카메오 간다] “한국영화에 매료 한국에 왔죠”", 2007.7.6, 스포츠 경향, "[카메오 간다] 한국영화 공부 외국 인 얼마나?”, 2007.7.6.

[72] 한국경제, "한국에서 영화공부 2 년, $35 \mathrm{~mm}$ 필름 에 담아내고파", 2007.7.27.

[73] 서울신문, "[글로벌 나눔 바이러스 2010] "한국서 $3 \mathrm{D}$ 기술 보고 눈이 번쩍” 이라크 촬영감독 자노”, 2010.4.24.

[74] 세계일보, ““상업적 작가주의” 시대 열었다”, 
2005.7.15.

[75] 문화일보, “영화아카데미, 2008 입학설명회”, 2007.4.14.

[76] 연합뉴스, “태풍' 제작자 박성근씨 영화아카데미 교수로”, 2006.1.3.

[77] 경향신문, “장편 데뷔작으로 주목받는 두 감독 “신재인 박성훈”, 2006.2.16.

[78] 서울신문, "여성 관객들이 위로받고 공감했으면 - 첫 장편 데뷔작 ‘어떤 개인 날' 이숙경 감독”, 2009.3.21.

[79] 스포츠경향, "레디고! 우리의 꿈엔 The End가 없답니다”, 2007.2.9.

[80] 서울경제, “손학규 전 지사 차녀 원평씨 단편영 화 출품”, 2007.4.26.

[81] 부산일보, “'칸'을 빛낸 또 다른 한국인 홍성훈 감독”, 2007.6.4.

[82] 스포츠경향, "성지혜 "내 삶의 여름은 이제부터 시작"”, 2007.1.26.

[83] 스포츠경향, “ '극락도 살인사건’ 제작자 최두영 “7전 8기만에 떴죠. 영화인생 이제 시작"”, 2007.5.4.

[84] 김정호, “스크린쿼터 축소의 영향분석”, 한국콘 텐츠학회논문지, 제 11 권, 제2호, p.249, 2011.

[85] 김동호, 한국영화 정책사, p.193, 나남출판, 2005.6.

[86] 위의 책, p.151.

[87] 위의 책, p.158.

[88] 헤럴드 경제, “충무로 '위기의 감독들”, 2010.4.3.

[89] 디지털 타임스, “스타 감독 발굴의 산실” 집중조 명”, 2008.2.1.

[90] 부산일보, ““미래 산업 청년리더 10만 명 양성” 정부, 6 개 분야 47 개 사업 5 년간 1 조원 투입”, 2008.9.12.

[91] 경향신문, “영화아카데미 제작연구과정 주목”, 2009.3.6.

[92] 스포츠경향, “한국영화아카데미, 개교 25주년 맞 아”, 2009.3.5.

[93] 매일경제, "영진위, 영화인 교육교재 4종 번역 출 간", 2009.9.27.
[94] 문화일보, "독립영화관 확대...... 스태프 임금 쿼터 도입, 영진위 사업 재편 “선택과 집중”, 2009.11.12.

[95] 한겨레, "진보적 감독 나올라 사전검열? 영진위 ‘영화아카데미 가위질”, 2010.3.18.

[96] 강병진, “간섭이 아니고 뭐야”, 씨네21, 2009.11.9.

[97] http://www.pressian.com/article/article.asp? article_num $=60081005154127 \&$ Section $=$

[98] 부산일보, “영진위 부산 이전 깔아뭉개기 물밑작 업”, 2008.9.22.

[99] 연합뉴스, "문화예술위, 문예진흥원으로 환원해 야”, 2008.5.7.

[100] 조희문, "이념과 선동의 레드카펫을 걷다: 한국 영화정책 10 년의 돌격”, 새 정부의 문화예술정 책- 문화예술기구 및 단체개혁 어떻게 할 것인 가?, p.79, 문화미래포럼 총서3, 집문당, 2008.

[101] 송낙원, "한국영화산업의 위기와 영화진흥위원 회: 부산이전 정책의 오류”, 위의 책, p.125.

[102] 김종국, "해체와 재구성을 통한 영화진흥위원 회 개혁방안", 위의 책, p.171.

[103] 김종국, 위의 글, p.188.

[104] 한겨레, "진보적 감독 나올라 사전검열? 영진위 ‘영화아카데미 가위질”, 2010.3.18.

[105] 조희문, 같은 글, p.83.

[106] 프레시안, "인디스페이스에 이어 미디액트도 사라지나, 영진위 지원 사업 공모 발표...... 엇 갈리는 의혹과 비판”, 2010.1.26.

[107] 프레시안, “독립영화 감독 155인, 새 독립영화 전용관 보이콧 선언”, 2010.218.

[108] 프레시안, ““창작자 권리 무시하나” 감독들 상 영거부에 오히려 상영확대. 시네마루, 이번에 아 카데미 감독 단편들까지 상영 예고", 2010.2.24.

[109] 스포츠경향, "한국영화아카데미 동문회, "학교 정상화 하라"”, 2010.2.8.

[110] 스포츠경향, ““영진위, 스스로 악덕기업이라 고 백하는가" 충무로도 영진위 비판, 공모 재검토 및 철회 요구”, 2010.2.24.

[111] 프레시안, "영진위 기능 정지됐다. 위원장 권력 
이 사유화되고 있다", 2010.3.10.

[112] 경향신문, “영화인들 ' 1000 인 선언'으로 영진위 정상화 촉구”, 2010.3.16.

[113] PD 저널, "문화예술인들도 "영진위 정상화 촉 구”", 2010.3.18.

[114] 오마이뉴스, "도 넘은 좌파 청산, 영화제까지 목 표물 되나”, 2010.3.23.

[115] 미디어스, "문화예술계, 뉴라이트 문화미래포럼 의 활약상?”, 2010.4.15.

[116] 컬처투데이, “집중 포화 맞은 조희문 영진위원 장”, 2010.3.18.

[117] 한국일보, “영화아카데미 내버려두시라”, 2010.3.1.

[118] 미디어스, "관객들은 제 2 의 봉준호, 최동훈을 만날 수 있을까", 2010.3.19.

[119] 연합뉴스, "조희문 "한국영화아카데미 변화해 야””, 2010.3.18.

[120] 방송법 제90조의2(시청자미디어센터), 2012.1.17, 본조신설.

[121] 스포츠경향, "문화부, 조희문 영진위 위원장 해 임", 2010.11.8.

[122] 머니투데이, "영화진흥위원회 위원장 김의석씨 선임”, 2011.3.29,

[123] 연합뉴스, "문화소식-영상자료원 세계영화사강 좌", 2011.1.19

[124] 세계일보, “장현수 감독, 한국영화아카데미 원 장 임명”, 2010.4.12.

[125] 연합뉴스, "영화아카데미 원장에 최익환 감독”, 2011.11.10.

[126] 장지영, “한국의 스티브 잡스를 키우려면”, etnews, 2010.6.7.

[127] 한국일보, “제2 봉준호, 최동훈' 미래형 인재 키 운다”, 2011.8.25.

[128] 이데일리, “공연계 숙원 '뮤지컬 아카데미' 생기 나”, 2012.8.20.

[129] 헤럴드 경제, "대중음악진흥위원회 설립추진위 원회 12일 발족", 2012.9.11.

\section{저 자 소 개}

김 정 호(Jung-Ho Kim)

정회원

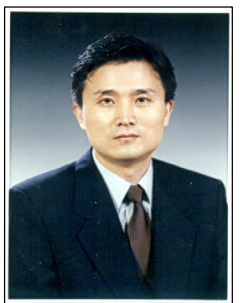

- 1992년 2월 : 고려대학교 심리학 과(학사)

- 1994년 3월 : 한국영화아카데미 영화연출 전공 졸업

- 2001년 6월 : California Institute of the Arts program in film \& video MFA.(예술실기석사)

- 2003년 3월 : 동서대학교 디지털영상매스컴학부 전임 강사

- 2004년 9월 현재 : 경희대학교 예술디자인대학 연 극영화학과 부교수

<관심분야> : 영화 영상제작, 영화사, 영화편집, 영화 경제, 뮤지컬, 오페라

\section{김 학 민(Hak-Min Kim)}

정회원

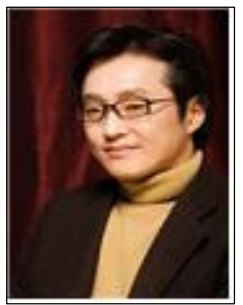

- 1985년 2월 : 고려대학교 영어영 문학과(학사)

- 1988년 2월 : 서울대학교 대학원 음악이론(석사)

- 2000년 1월 : 미국 오스틴텍사스 주립대학(박사: 오페라 연출)

- 2003년 2월 현재 : 경희대학교 예술디자인대학 연 극영화학과 부교수

<관심분야> : 뮤지컬, 오페라, 연기, 연출, 영화 